\title{
地震による損傷を制御可能な新型橋梁用 支承サイドブロックの研究
}

\author{
張＼cjkstart広鋒 $1 \cdot$ 蔵治 賢太郎 $2 \cdot$ 和田 新 $3 \cdot$ 右高 裕二 $4 \cdot$ 大住 圭太 5 \\ 1正会員 一般財団法人首都高速道路技術センター 技術研究所（†105-0001 東京都港区虎ノ門 3-10-11） \\ E-mail: g.zhang@tecmex.or.jp \\ 2 正会員 首都高速道路株式会社 技術部（干100-8930 東京都千代田区霞ヶ関 1-4-1） \\ E-mail: k.kuraji66@shutoko.jp \\ 3 正会員＼cjkstart首都高速道路株式会社＼cjkstart東京西局プロジェクト本部（†114-0002 東京都北区王子 1-8-1） \\ E-mail: a.wada116@ shutoko.jp \\ 4 正会員 首都高速道路株式会社＼cjkstart東京西局プロジェクト本部（干114-0002 東京都北区王子 1-8-1） \\ E-mail: y.migitaka1413@ shutoko.jp \\ 5 正会員 一般財団法人首都高速道路技術センター 技術研究所（†105-0001 東京都港区虎ノ門 3-10-11） \\ E-mail: osumi@tecmex.or.jp
}

\begin{abstract}
近年の地震では，橋梁支承のサイドブロックの損傷が多く確認されている. 破断した取付ボルトや取付 ボルトの破断によって脱落したサイドブロック本体が高架下に落下すると第三者被害を引き起こす恐れが ある。このようなリスクを回避するための対策として，著者らは，サイドブロック凸部の塑性挙動を利用 して, 取付ボルトの破断などの脆性破壊を生じさせない新たな損傷制御型サイドブロック（DCSB）の研 究を行った。検討では，DCSB の凸部形状および取付ボルトの配置方法の提案を行った上，実大 DCSB 供 試体に対して静的載荷実験および動的加振実験を実施し，DCSB の耐荷性能や損傷の制御が設計通りであ ることを確認した。 また，動的加振実験結果に基づき，DCSB の塑性変形の進展に伴う橋梁上部構造の動 的特性の変化も明らかにした。
\end{abstract}

Key Words : bridge bearing, seismic performance, side block, damage control

\section{1. はじめに}

近年，橋梁用支承サイドブロックの地震損傷が多数報 告されている例えば，1) 4)．損傷には，取付ボルトやサイド ブロックの変形・破断の他，取付ボルトの破断に伴った サイドブロック本体の脱落，さらに脱落したサイドブロ ック本体が高架下に落下した事例があった．図-1 に， 東日本大震災におけるサイドブロックの被害例を示寸． 本サイドブロックは，高架下への落下に至らなかったが, 取付ボルトの破断によって橋脚上に脱落していた．破損 したサイドブロック部材が高架下に落下すると，通行人 や通行車両に第三者被害を引き起こす恐れがある。また， 仮にこれらの破損部材が橋脚上に留まったとしても，余 震で落下寸る恐れがあり，地震後の緊急点検や応急復旧 作業の阻害要因になる可能性もある.

サイドブロックの設計では，一般に，許容応力度法を 用いて設計地震力に抵抗できるようにサイドブロック本

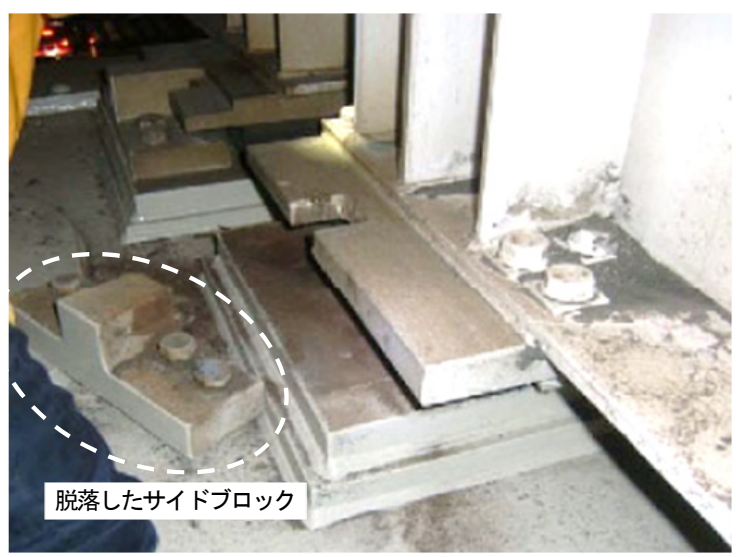

図-1＼cjkstart橋脚上に脱落したサイドブロック

体と取付ボルトの耐力を設計する ${ }^{5}$ ．しかし，設計地震 力より大きな地震力が作用する場合のサイドブロックの 挙動，いわゆる，設計で考慮していた終局状態を超えた 状態のサイドブロックの挙動については，設計上で明確 
に考慮していないのが現状である．また，サイドブロッ クの地震損傷の制御については, 免震支承のサイドブロ ックに関する研究が報告されているが, 凸部を設計通り に破断させ移動拘束を解放させるための研究であり, 移 動拘束解放後の凸部の挙動の制御について特に論じられ

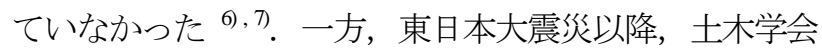
では構造物の危機而性の概念が提案されている例え゙゙，8). 橋梁耐震上の危機而性とは, 大地震によって構造物が設 計で考慮していた状態を超えた状態になることへの対応 を考慮することである. ここで，支承サイドブロックに 着目すると, 設計で考慮していた状態を超えた状態であ る破断や落下と言った事象を設計段階で配慮することと すれば，第三者被害や地震後の緊急作業への阻害などの リスクを低減させることが可能となり，橋梁全体の地震 時危機而性の向上にも繋がる. 首都直下地震などの大地 震の逼迫性が指摘される中 ${ }^{9}$, このように, 支承サイド ブロック部材の落下リスクを低減させる対策の構築は橋 梁の地震防災上重要な意味があると考えられる.

このような状況を踏まえ，著者らは，地震時における 支承サイドブロック部材の落下による第三者被害のリス クの低減対策として, 凸部の塑性挙動を利用する新たな サイドブロックの提案を行った. 提案したサイドブロッ クは, 従来のサイドブロックと異なるコンセプトのもの で，凸部の塑性変形を利用してサイドブロックとしての 耐荷挙動を制御するとともに，終局時においても取付ボ ルトや凸部の脆性破壊を生じさせないようにするための 損傷制御型のものである．検討では，三次元弾塑性 FEM 解析に基づき構造ディテールを検討した上 ${ }^{10), 11)}$, 実物大供試体に対して静的載荷実験および動的加振実験 を実施し，提案したサイドブロックの耐荷性能の検証お よび橋梁の地震時挙動への影響の検討を行った. 本論文 は，提案したサイドブロックの基本コンセプト，その性 能を検証するための実験結果および提案のサイドブロッ クを用いた橋梁の地震時挙動の検討結果を報告するもの である.

\section{2. 損傷制御型サイドブロックの提案}

\section{(1) サイドブロックの損傷原因の考察}

支承のサイドブロックは，主桁の橋軸直角方向（以下， 橋直方向と呼ぶ）の横移動を抑制するためのものである. サイドブロックの構造には, 支承の下沓と一体となって いるものもあるが，凸部，フランジおよび取付ボルトに よって構成されるものが殆どである（図-3 を参考）。 設計では, 一般に取付ボルトの降伏強度を用いてサイド ブロックとしての耐力を定める. 設計に用いる外力は, 一般に, 橋直方向の地震力に対して一支承線上の全支承
のサイドブロックが均等に抵抗する前提の個々のサイド ブロックの負担分とする. このように設計されたサイド ブロックは, 設計で考慮した地震力に対しては, 取付ボ ルトの塑性破壊が生じないが, 設計以上の地震力が作用 する場合は，取付ボルトや凸部に塑性変形が生じ，破断 に至ることがある.

一方, 実橋梁の場合は, 地震の不確定性, 実構造の地 震時挙動の複雑さ, 支承の据付誤差などの影響要因があ り, 実務設計・施工において地震力の一部のサイドブロ ックへの偏りを完全に回避することが困難である，その ため, 一支承線上の全サイドブロックではなく，一部の サイドブロックに全地震力が作用する場合がある。 その 結果, 設計で考慮した地震動より小さい地震においても, 一部のサイドブロックに作用する地震力が設計地震力を 上回り, サイドブロック部材が塑性破壊や破断に至るこ ととなる.

\section{（2）損傷制御型サイドブロックの基本思想}

サイドブロック部材の高架下への落下を回避するため の方法として，1つは，支承本体から脱落したサイドブ ロック部材の落下を防止するための対策を構築すること, もう1つは，サイドブロックに損傷が生じたとしても， 支承本体からの脱落を生じさせない上うにすることの 2 つのアプローチが考えられる. 前者の場合は, サイドブ ロックに落下防止チェーンなどを設置する事例がある.

本研究では，後者の考え方をもとに，地震損傷を制御可 能な新たなサイドブロックを提案することとした．提案 したサイドブロックの基本思想は，以下のようである.

1) 目標とする性能 従来のサイドブロックと同様に上 部構造に対する橋直方向の移動拘束を基本機能とし ながら, 大地震時に下部構造に設計以上の地震力が 作用しない，かつ取付ボルトや凸部の脆性破壊を生 じさせないようにするものとする.

2) 而荷性能の制御 凸部の塑性挙動を利用し，凸部の 降伏や上部構造に対する移動拘束を解放することに よって, 下部構造に過大な外力が作用しないように する.

3）損傷形態の制御 凸部の形状を工夫し，高い変形性 能を持たせるとともに, 終局においても破断を生じ させないこととする. また, 取付ボルトと凸部の耐 力階層化を考慮し, 凸部の終局耐力に対する取付ボ ルトの耐力に適切な安全余裕度を持たせることによ って, サイドブロックが終局に至ったとしても取付 ボルトの破断を防止することとする.このような工 夫によって, 地震時の取付ボルトの破断並びにサイ ドブロック本体の脱落を防止することが可能と考え られる。

本研究では，このような性能を有するサイドブロック 


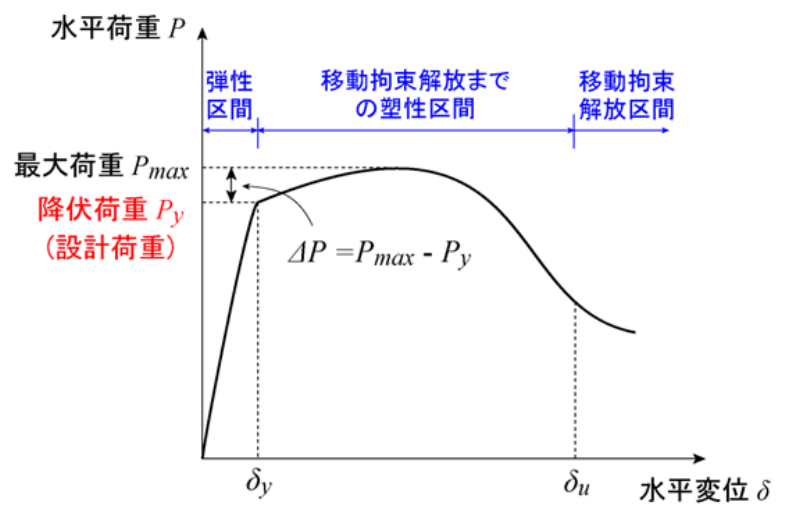

図-2 DCSB 凸部の水平荷重一水平变位関係のイメージ図

を損傷制御型サイドブロック（Damage-Controlled Side Block, DCSB）と名付けた.

\section{(3) DCSB の耐荷性能と変形性能の制御}

DCSB に目標の性能を持たせるため，図-2 に示寸水平 荷重一水平変位関係を有する凸部を検討することとした. すなわち，凸部は，設計で考慮した地震力に対して弾性 状態で抵抗するが，それ以上の地震力が作用すると凸部 が降伏し，過大な外力に抵抗しないようにする．さらに， 一定の塑性変形が生じた後, 上部構造の横移動拘束を解 放する．ここでの塑性変形区間は，後述の図-4 に示寸 ように，移動拘束を解放させるために必要な塑性変形量 であり，一支承線上の各サイドブロック間の地震力の再 分配にも役立つものとなる．降伏後の塑性変形区間では, 凸部が設計耐力を維持したままで一定の塑性変形が可能 であるため, 一支承線上の特定のサイドブロックに地震 力が先に作用したとしても，他のサイドブロックが抵抗 するまで設計耐力を維持して変形し, 最終的に設計通り 全てのサイドブロックが連動して地震力に抵抗すること が実現可能と考えられる.

設計において凸部の耐力を制御しやすく寸るため，図 -2 に示寸ように, 凸部の降伏によって耐力の増加勾配 が急に低下した時点の耐力（降伏耐力）を凸部の設計耐 力とした. 設計より過大な外力を受けないようにするた めには，降伏後の耐力が増加しないことが理想であるが， 金属材料の硬化特性などより, 降伏後の耐力の増加分 $\Delta P$ をゼロにすることは極めて困難である．検討では, 後述のように, 凸部の形状の工夫などによって降伏後の 耐力の増加を抑制することとした．このような思想に基 づいた検討の結果，DCSB の形状は図-3 に示寸ものとな った.

図-4に, DCSB の損傷制御のイメージ図を示寸. DCSB では，図-4 に示すように，凸部の水平変形による 凸部頂部の高さの低下を利用して移動拘束を解放させる ことにした. 寸なわち, 凸部の水平変形の増大に伴って 凸部天端の高さが徐々に下がり, 最終的に上沓下面より

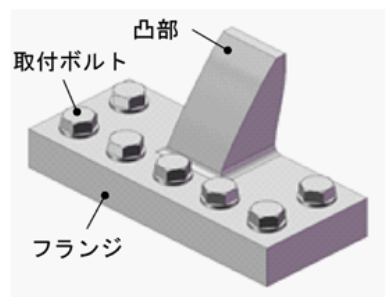

(a) 全体

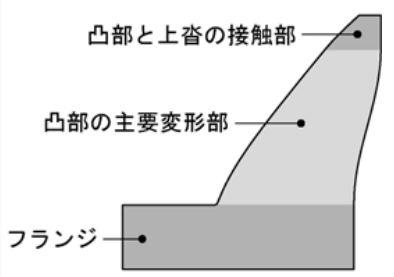

(b) 断面形状
図-3 DCSBのイメージ図

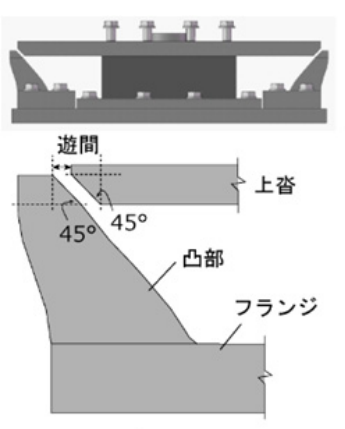

(a) 変形前

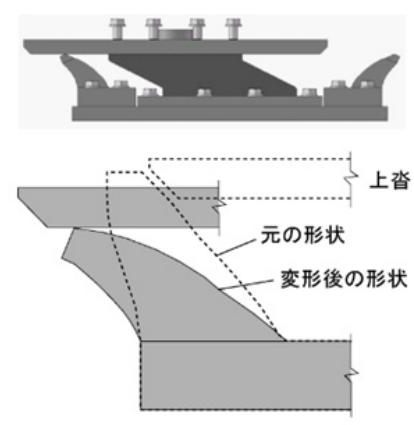

(b) 終局（移動拘束解放後）
図-4 DCSB の損傷制御のイメージ図

低い位置になることによって上沓の移動拘束が解放とな る. 以降の考察では, 図-4(b) の凸部の状態を終局状態 と定義する. なお, 本研究では, 終局状態に達寸るまで の DCSB の塑性挙動を検討することとしたが，移動拘束 を完全に解放させなくても，下部構造に過大な地震力を 作用させないことが実現可能となる. 図-2 に示すよう に, 移動拘束解放までの塑性区間では耐力の増加が少な いため，凸部の変形状態が塑性区間に留まったとしても， 下部構造に過大な地震力を伝達しないこととなる.

\section{（4）検討すべき課題点の抽出と検討内容}

上記のことを実現させるためには，DCSB 凸部に高い 変形性能を持たせるとともに, 凸部の亀裂や破断を生じ させないようにする工夫が必要となる. また, 取付ボル 卜の破断を生じさせないように，取付ボルトの抵抗耐力 を向上させるための改善策の検討も必要である.さらに, DCSB を用いた橋は，地震時において上沓と DCSB 凸部 の繰返し衝突，凸部の塑性変形の増大に伴う拘束効果の 低減による上部構造の振動特性の変化などが予測される. DCSB の実用化に向けて，DCSB を用いた橋梁の地震時 挙動を明らかにする必要がある.

これらを踏まえ, 本研究では, 三次元 FEM 解析に基 づき凸部の基本形状および取付ボルトの配置方法を提案 した上，実物大 DCSB 供試体に対した静的載荷実験およ び動的加振実験を実施し，DCSB の基本思想の妥当性の 確認および DCSB の性能の検証を行った．また，動的加 振実験結果に基づき, DCSB を用いた橋梁の上部構造の 動的挙動を検討した. 以下に, これらの検討内容につい 
表-1 材料物性

\begin{tabular}{c|c|c|c|c|c}
\hline 材料 & $\begin{array}{c}\text { 降伏 } \\
\text { 点 } \\
(\mathrm{MPa})\end{array}$ & $\begin{array}{c}\text { 引張 } \\
\text { 強さ } \\
(\mathrm{MPa})\end{array}$ & $\begin{array}{c}\text { 降伏 } \\
\text { 比 } \\
(\%)\end{array}$ & $\begin{array}{c}\text { 伸び } \\
(\%)\end{array}$ & $\begin{array}{c}\text { 吸収 } \\
\text { エネギー } \\
(\mathrm{J})\end{array}$ \\
\hline \hline 本材料 & $200 \sim 260$ & $300 \sim 400$ & 55 以上 & 35 以上 & 47 以上 \\
\hline SCW480 & 275 以上 & 480 以上 & - & 20 以上 & 27 以上 \\
\hline
\end{tabular}

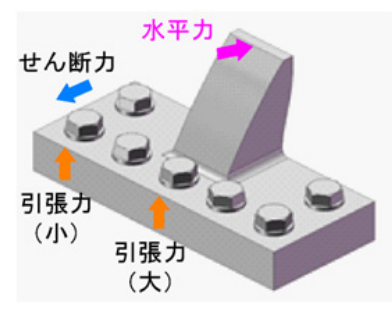

(a) 橋直方向に作用する場合

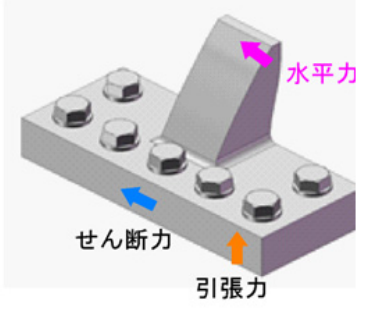

(b) 橋軸方向に作用する場合
図-5 DCSB 凸部頂部の水平力による軸力のイメージ図

\section{て詳細に説明する.}

一方，本研究では，DCSBの材料として新たな鋳鋼品 材料を採用することにした．表-1 に，本材料と一般的 な鋳鋼品材料である SCW480 の材料物性の一覧を示寸. 本材料は, SCW480 と比へ，高い伸び性能とともに，降 伏点や引張強さが一定の範囲にある特徵がある。このよ うなことは，DCSB 凸部の高い変形性能の確保や降伏而 力の制御に有利と考えられる．また，本材料は，鋳鋼品 であるため, DCSB の厚い板厚や複雑な形状にも対応し やすい. なお，本材料の弾性係数は，一般的な鋼材と同 様の $2.1 \times 10^{5} \mathrm{~N} / \mathrm{mm}^{2}$ 程度である.

\section{DCSB の構造ディテールの検討}

\section{(1) 凸部の基本形状の検討}

凸部に塑性変形が局部的に集中寸ると，小さな水平変 形量でもき裂が生じる恐れがある. 本研究では，このよ うなことを回避するために, 高さ方向の全断面が同じ夕 イミングで降伏するように凸部の断面形状を設計し，凸 部の塑性変形を高さ方向に分散させるようにした，具体 的には，凸部頂部に作用する水平力に対して，式(1)を 用い, 凸部高さ方向の各断面の合成応力度 $\sigma_{c}$ が同じと なるように，橋直方向の断面幅（橋軸方向断面幅は一定） を設計することにした.

$$
\sigma_{c}=\left(\frac{\sigma}{\sigma_{y}}\right)^{2}+\left(\frac{\tau}{\tau_{y}}\right)^{2}
$$

ここに， $\sigma_{c}$ は凸部高さ方向の照査断面の合成応力度 である. $\sigma$ および $\tau$ は, 照查断面の直応力度 $\left(\mathrm{N} / \mathrm{mm}^{2}\right)$ お よびせん断応力度 $\left(\mathrm{N} / \mathrm{mm}^{2}\right)$ である， $\sigma_{y}$ および $\tau_{y}$ は，降 伏応力 $\left(\mathrm{N} / \mathrm{mm}^{2}\right)$ および降伏相当のせん断応力 $\left(\mathrm{N} / \mathrm{mm}^{2}\right)$ で

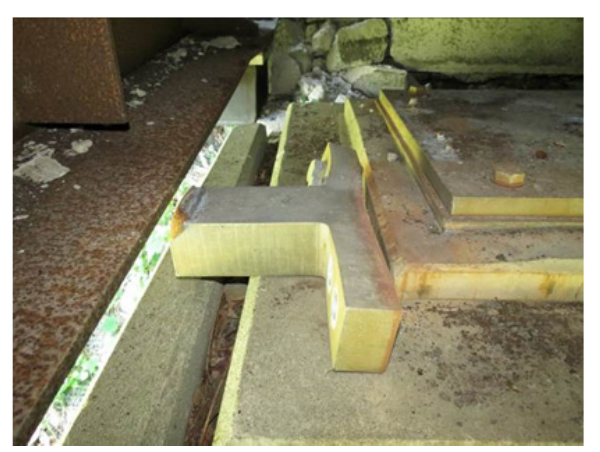

図-6 近年の地震におけるサイドブロックの損傷事例
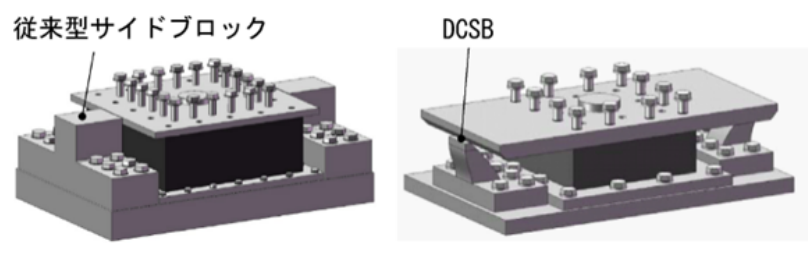

図-7従来型サイドブロックと DCSB を実装したゴム支承

ある. 式 (1) に基づいた凸部の高さ方向の断面形状は, 曲げモーメントが大きく生じる基部では断面幅が大きく, 上部方向に向かうにつれて断面幅が小さくなっていくも のとなった. 図-3に凸部の断面形状のイメージ図を示 す.ここで，凸部圧縮側の形状については，本研究では 降伏後の耐力増加の抑制を図るため, 便宜的に cos 曲線 形状にした．このような形状にした場合は，上沓による 水平力の作用によって凸部が曲がりやすくなり, 従来の 直立形状の場合と比へ，降伏後の耐力の増加が少ないこ とを解析的に確認した ${ }^{10)}$. なお，他の曲線形状にしても 降伏後の耐力増加の抑制効果を得られることが可能と考 えられるが，凸部の変形性能と圧縮側の形状の関係を明 らかにするためにはさらなる検討が必要となる.

\section{（2）取付ボルトの配置方法の検討}

図-5 に示すように，DCSB 凸部頂部に水平力が作用す る場合の取付ボルトには, 水平地震力に釣り合うせん断 力の他，水平地震力による曲げモーメントによって引張 の軸力も発生する．橋直方向に水平力が作用する場合の てこ反力や，橋軸方向に水平力が作用寸る場合の橋直方 向まわりの曲げモーメントなどにより, 配置位置によっ てボルトの軸力が異なってくることが予測される. 取付 ボルトの配置位置を検討するための三次元 FEM 解析に おいてもこのようなことを確認した ${ }^{11)}$.また，凸部の耐 力に対して取付ボルトやフランジの耐力が不十分な場合 は, ボルトの塑性変形, フランジの浮き上りや変形, さ らにボルトの破断が生じる可能性がある. 図-6に，近 年の地震におけるゴム支承のサイドブロックの損傷事例 を示す. 本損傷事例では, サイドブロックのフランジ中 央付近の面外変形と取付ボルトの破断が生じた. 


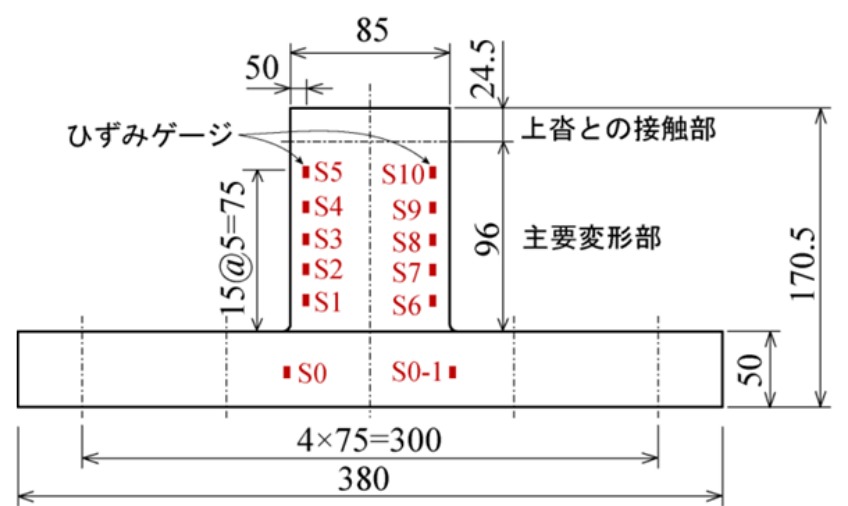

(a) 側面図

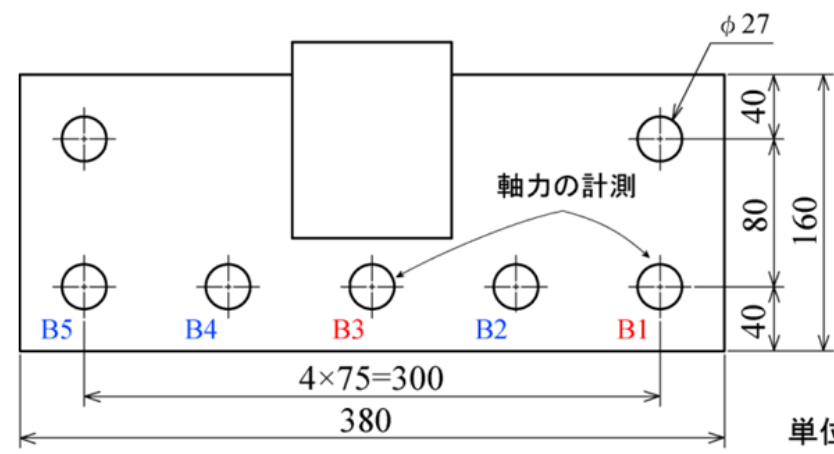

(c) 平面図

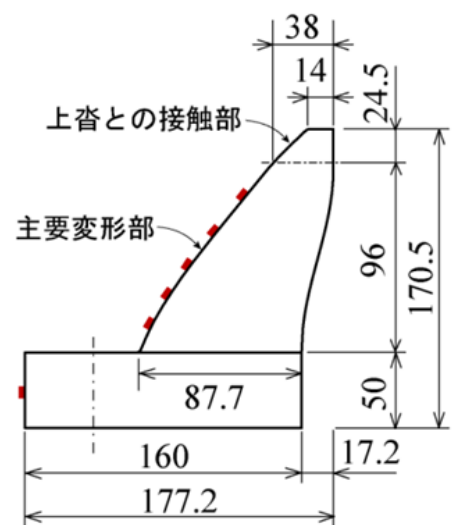

(b) 断面図

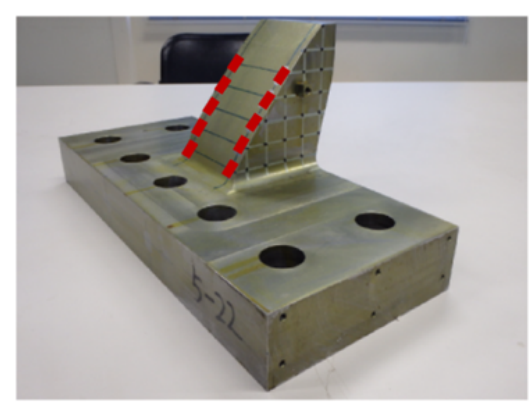

(d) 供試体写真

図-8 鈆直最大反力 $500 k N$ 支承用 DCSB の形状寸法および供試体写真

以上のことを考慮に入れ, 本研究では, 地震力に対す る取付ボルトの抵抗力の向上を図るため，図-5に示す 取付ボルトの配置方法を提案することとした．ここで， 参考として，図-7に，従来型サイドブロックと DCSBを 実装したゴム支承のイメージ図を示寸，提案の配置方法 では，従来型サイドブロックの配置方法と比べ，凸部前 面にボルトを多く配置し，地震力によるフランジの浮き 上がりに対するボルトの抵抗を高めるようにした.

\section{(3) DCSB の試設計}

DCSB の形状寸法の確認や性能確認実験に使用する供 試体の設計を行うため, 鉛直最大反力 $500 \mathrm{kN}$ 程度の支承 を想定し，設計水平震度を 0.78 と仮定して DCSB の試設 計を実施した。ここでの 0.78 は，道路橋示方書に準拠 して, 許容塑性率を 3.0 としたレベル 2 タイプ II 地震動 （II 種地盤）の設計水平震度である ${ }^{12}$ ）また，実橋梁の 設計では，一般に死荷重比率を 6 割程度とし，鉛直最大 反力 $500 \mathrm{kN}$ の支承を用いる場合の上部構造の死荷重を $300 \mathrm{kN}$ 程度と寸る.このような状況を参考とし，本研究 では凸部の設計耐力の目標值を便宜的に $300 \mathrm{kN} \times 0.78=$ $234 \mathrm{kN}$ とした. 図-8に，試設計した DCSB の形状寸法と 供試体写真を示す。

凸部の設計では，凸部の橋軸方向と高さの寸法を一般 的なゴム支承の場合の寸法とした上，設計耐力と合成応 力度 $\sigma_{c}$ を用い, 高さ方向に $5 \mathrm{~mm}$ 間隔で各断面の寸法を
計算した. 具体的には，凸部と上沓の接触部の中心（以 下，接触部中心）に設計耐力と等しい外力を作用し，式 (1) による合成応力度 $\sigma_{c}$ が降伏時の合成応力度である 1.0 程度となるように, 各断面の直応力度 $\sigma$ とせん断応力度 $\tau$ を用いて断面の橋直方向の寸法を決定した. 設計の結 果, 塑性変形を期待する主要変形部（上沓との接触部を 除き）は，高さは $96 \mathrm{~mm}$ で，基部と頂部の橋直方向の 断面幅はそれぞれ $87.7 \mathrm{~mm}$ と $38 \mathrm{~mm}$ となっている.

取付ボルトについては，強度区分 8.8 を基本とし，従 来のサイドブロックと同様に許容応力度法を用いて設計 した．具体的には，接触部中心に作用する設計外力に対 して，ボルトに生じた引張応力とせん断応力の合成応力 度が許容值内に収まるようにボルトの必要断面積を計算 した，その計算結果に基づき，市販のボルトにて呼び径 M24のものとなった.

フランジについては，従来のサイドブロックの設計に おいても応力の照査は特に実施されない状況を考慮に入 れ, 本研究では, 従来型サイドブロックの寸法を参考に してフランジの板厚を便宜的に 50mm とした．設計では， 接触部中心に作用寸る設計外力に対して凸部両側のフラ ンジ断面だけが抵抗することとして，凸部の設計耐力に 対してフランジのせん断応力が降伏応力に至らないこと を照査した. 三次元 FEM 解析においても，凸部の最大 耐力に対するフランジの応力が降伏応力に至らなかった ことを確認した ${ }^{11)}$. 
図-8に，後出の実験における DCSB のひずみやボルト 軸力の計測箇所の概要も示寸. 凸部については, 主要変 形部の高さ方向の 5 断面においてひずみの計測を行った. 取付ボルトについては, フランジの端部と中央の B1 と B3 ボルトに対して, 埋込ボルトゲージを用いて軸力の 計測を行った. なお，動的加振実験も含めた一連の実験 では，凸部のひずみ計測に計測範囲 20,000 $\mu$ の泊ひずみ ゲージを使用した。

\section{4. 静的載荷実験}

\section{（1）静的載荷実験の概要}

図-9 に，静的載荷実験の設置概要を示寸．実験では, 供試体の DCSB 単体を対象とし, 載荷プレートを用いて DCSB 凸部を所定の変形量まで 1 方向に載荷した。 ここ で，DCSB 凸部の所定の変形量とは，図-4 に示すように, DCSB 凸部天端が載荷プレートより低くなるための変形 量である，供試体の設置では，実橋梁の支承の設置状況 を参考とし，DCSB 凸部と上沓間の遊間を $5 \mathrm{~mm}$ 程度と なるように調整した．後出の動的加振実験でも同様に供 試体を設置した，そのため，実験結果の水平変位は，凸 部の変形量にこの遊間量を足し合わせたものとなってい る. 取付ボルトの締付けについては, 実橋梁のサイドブ ロック組立て作業と同様に，電動工具を用いた締付けを 行った.

載荷では, 1 方向単調載荷と地震力の作用状況を想定 した片方向変位漸増繰返し載荷の 2 種類の載荷方法とし, それぞれ 1 体の供試体を実験した。両ケースの載荷速度

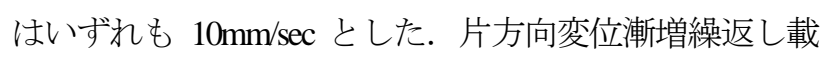
荷では, 所定の変位増分 $\delta$ を用い, $1 \delta$ 載荷 $\rightarrow$ 除荷 $\rightarrow 2 \delta$ 載荷 $\rightarrow$ 除荷 $\rightarrow 3 \delta$ 載荷... と言った載荷ステップで凸部が 終局状態になるまで繰返し載荷を行った。変位増分 $\delta$ は, 凸部の降伏前は $1 \mathrm{~mm}$ とし, 凸部の降伏後は $10 \mathrm{~mm}$ とし た. また, 各載荷ステップでは, 所定の変位量まで載荷 した後, 変位がゼロになるまで除荷を行った.

計測項目は，水平載荷荷重，載荷プレートの水平変位 (凸部の水平変形量)，凸部とフランジのひずみおよび 取付ボルトの軸力とした。

\section{（2）静的載荷実験結果}

図-10に, 両載荷ケースの水平荷重-水平変位曲線, 凸部ひずみ一水平変位曲線および凸部の変形状況写真を 示寸.

DCSB の水平抵抗特性は, 両載荷ケースとも, 弾性区 間, 移動拘束解放までの塑性変形区間と移動拘束解放後 に分けられる. 水平変位 $10 \mathrm{~mm}$ 程度までの水平荷重は, 概ね線形的に増加した。 凸部のひずみ曲線から分かるよ

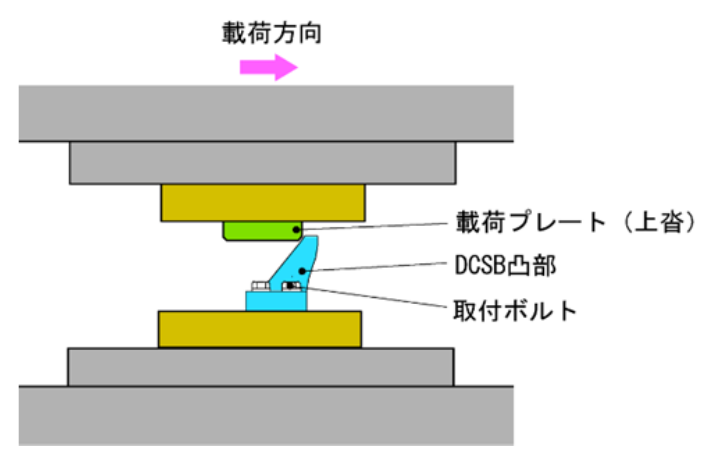

図-9 静的載荷実験の設置状況の概要

うに，凸部のひずみ S1～S5 は水平変位 $9.0 \mathrm{~mm}$ 付近で一 斉に降伏ひずみに達したことより, 水平変位 $10 \mathrm{~mm}$ まで の凸部は概ね弾性的に挙動したことが言える.

移動拘束解放までの塑性区間では，水平荷重が水平変 位 $25 \mathrm{~mm}$ 程度まで概ね同程度の值を保持した。両載荷ケ 一スの降伏荷重と最大荷重は，単調載荷の場合は $250.8 \mathrm{kN}$ （水平変位 $9.9 \mathrm{~mm}$ ） と $250.6 \mathrm{kN}$ （水平変位 $26.3 \mathrm{~mm}$ ），繰返し載荷の場合は $239.0 \mathrm{kN}$ （水平変位 $10.1 \mathrm{~mm}$ ）と $244.0 \mathrm{kN}$ （水平変位 $25.0 \mathrm{~mm}$ ）であった. 降伏 後の耐力の増加は $2 \%$ 程度（繰返し載荷）であった。 こ こで，降伏後の耐力の増加が少ないことより，降伏から 最大荷重時までの区間を耐力一定区間と呼ぶ. 水平変位 $30 \mathrm{~mm}$ 付近の凸部の変形状況を見ると, 凸部全体が緩や かに曲がっていることが見られる.

最大荷重に達した後の耐力低下区間と移動拘束解放後 では，水平変位の増加に伴って水平荷重が徐々に低下し， 水平変位 $50 \mathrm{~mm} \sim 60 \mathrm{~mm}$ 付近で凸部が終局状態になった. 右下の水平変位 $60 \mathrm{~mm}$ 付近の写真より, 載荷プレートが 凸部頂部を乗り越え, 凸部が終局状態に達した状況が見 られる. 移動拘束解放後の水平荷重は, 載荷プレートと 凸部間の摩擦によって生じたものである.

両載荷ケースの水平荷重一水平変位曲線の比較より, 降伏荷重や最大荷重に多少の差が生じていたが，両ケー スが同様な曲線を示し，繰返し荷重による凸部の耐荷性 状の変化は特に見られなかった。 また， 凸部のひずみ S1〜S5 が同じ水平変位で降伏ひずみに達したことより， 凸部の高さ方向の特定の断面にひずみが集中することは なく, 設計思想の通りに同じタイミングで降伏したこと が言える. 実験後の観察より, 両載荷ケースとも凸部に き裂が生じていなかったことを確認した。

図-11 に, 両載荷ケースの水平荷重一水平変位曲線と ボルト軸力ー水平変位曲線を示す. 図より, フランジ中 央のボルト B3 と端部のボルト B1 とも, 水平荷重の増 減に従って軸力が変化していたことが見られる. 軸力の 最大值は B3 の方が B1 より大きかった. 両実験ケース における B3 の軸力の最大值は $78.9 \mathrm{kN}$ であり, 使用した ボルトの保証耐力 $212 \mathrm{kN}$ の $37 \%$ 程度であった。 

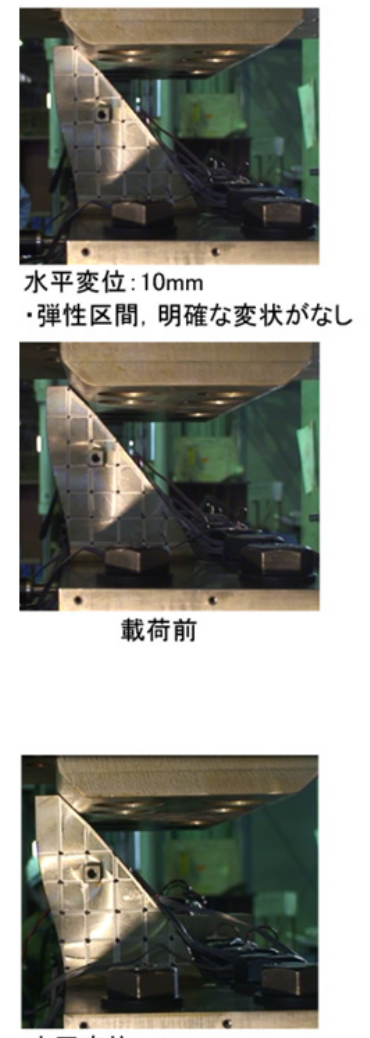

水平変位: $10 \mathrm{~mm}$

·弾性区間, 明確な変状がなし

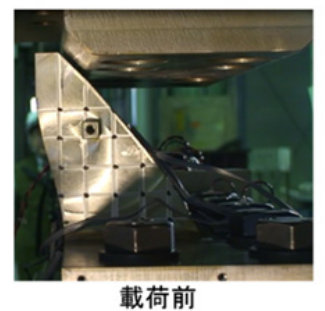

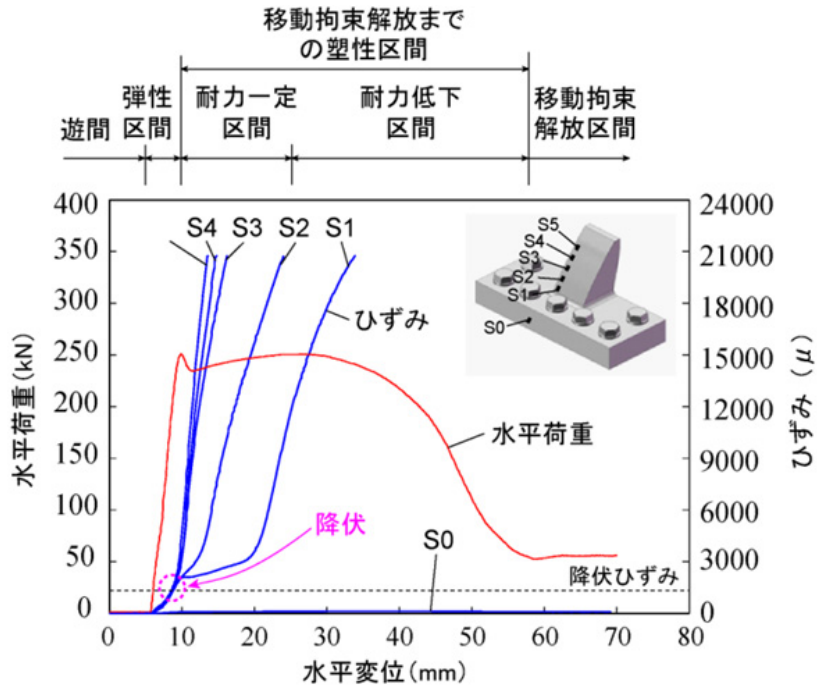

(a) 単調載荷

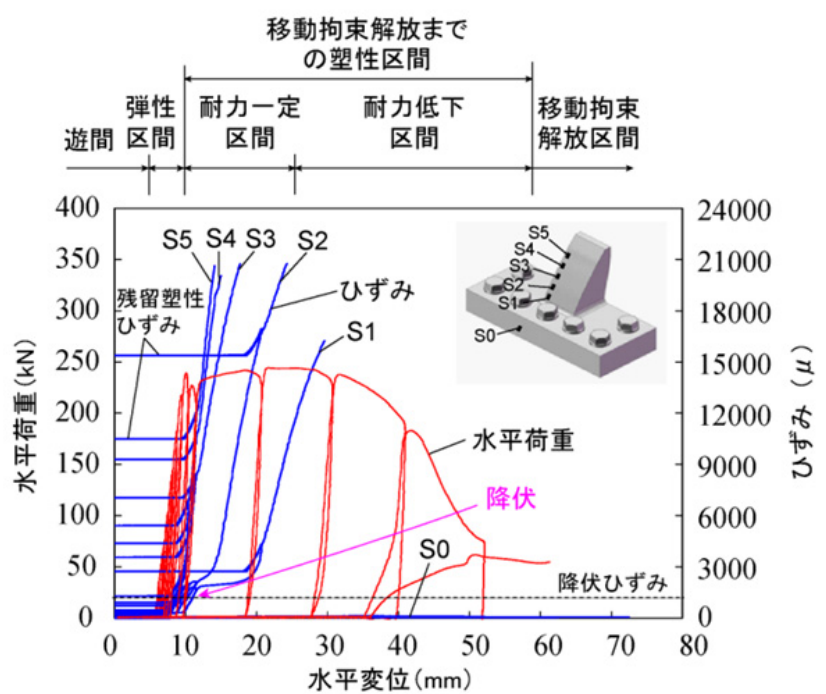

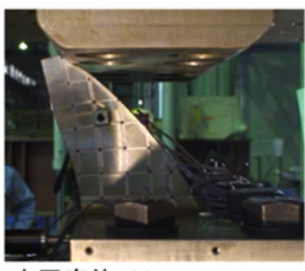

水平変位: $30 \mathrm{~mm}$

·凸部が大きく曲がっている

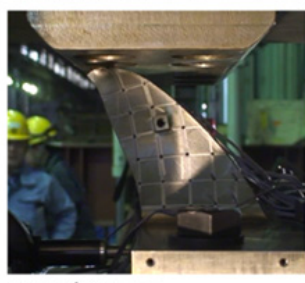

水平変位: $60 \mathrm{~mm}$ ·終局状態, 移動拘束解放

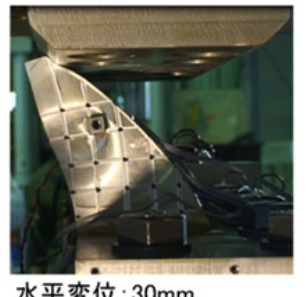

水平変位: $30 \mathrm{~mm}$ •凸部が大きく曲がっている

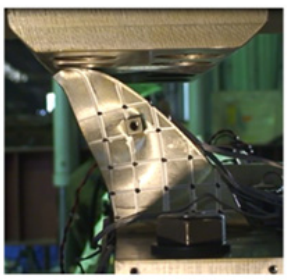

水平変位: $60 \mathrm{~mm}$ ·終局状態, 移動拘束解放

(b) 片方向変位漸増繰返し載荷

図-10 静的載荷実験結果の水平荷重一水平変位曲線，凸部ひずみ一水平変位曲線および凸部の変形状況写真

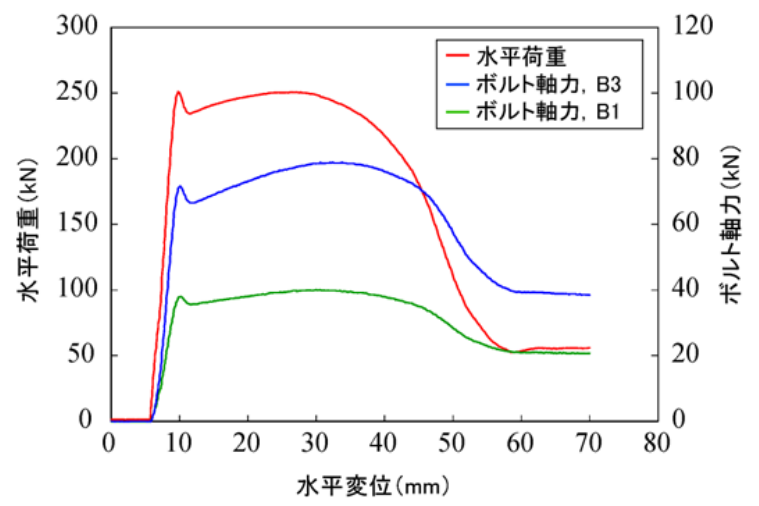

(a) 単調載荷

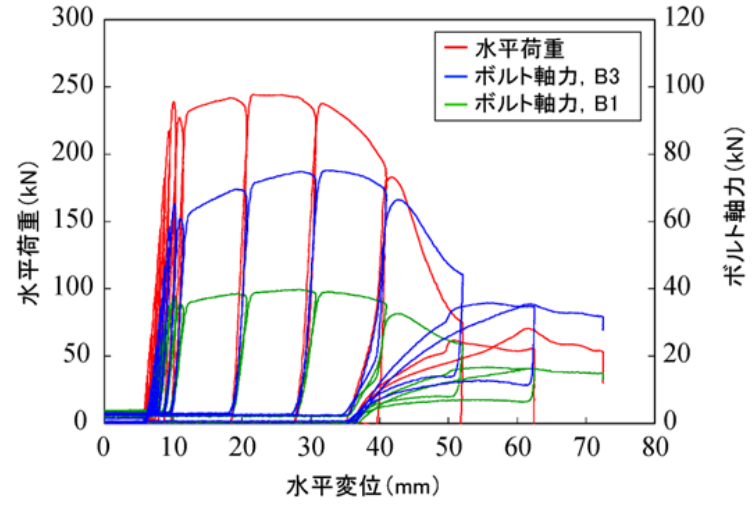

(b) 片方向変位漸増繰返し載荷

図-11 静的載荷実験結果の水平荷重一水平変位曲線とボルト軸力一水平変位曲線

\section{5. 動的加振実験}

(1) 動的加振実験の概要

動的加振実験では，国立研究開発法人土木研究所が所
有する三次元大型振動台を使用した．図-12 に実験の設 置状況の概要を示寸.

実験では，振動台テーブル上に加振装置と供試体の DCSB を設置し, 所定の地震波形を入力することによっ 


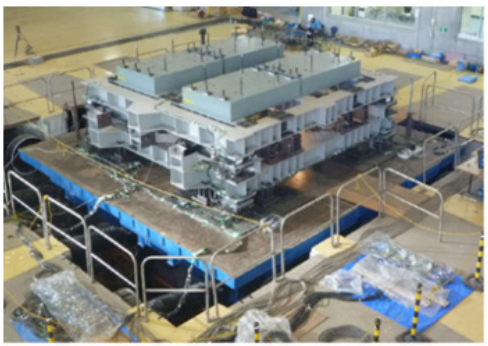

加振装置の全景写真

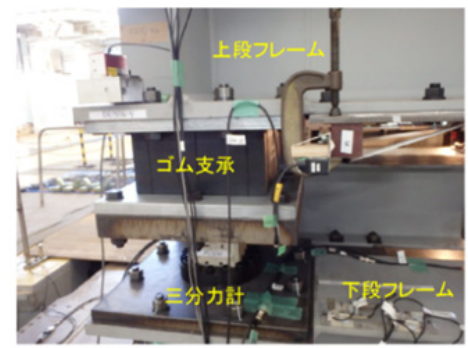

支承と三分力計の状況写真
·加速度計測 : 上段フレーム中央, サーボ式加速度計

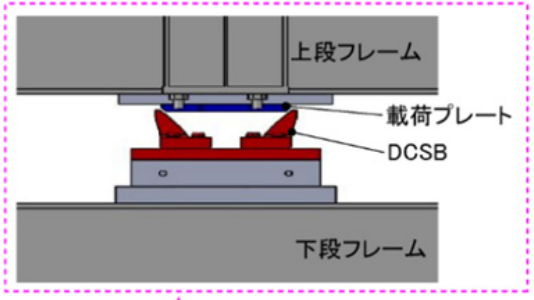

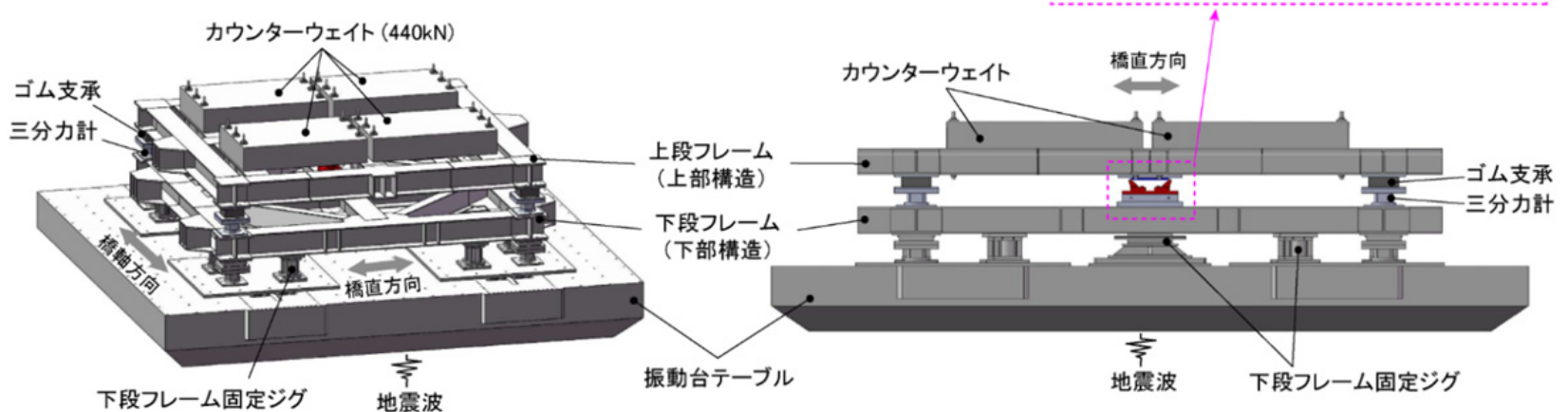

加振装置の立体図

図-12 動的加振実験の設置状況の概要

て加振を実施した．加振装置は，橋梁の上部構造を模擬 する上段フレームと DCSB を設置するための下段フレー ムによって構成されている. DCSB 供試体は, 下段フレ 一ムの上面中心に 2 体を設置した. 同じ位置の上段フレ 一ム下面に載荷プレート（上沓）を設置し，この載荷プ レートと 2 体の供試体の組合せを用いることによって DCSB を実装した支承の構造を模擬することとした. フ レームの四隅のゴム支承部には三分力計を設置し，それ ぞれの支承反力を計測することとした．表-2 に上段フ レーム四隅のゴム支承の仕様を示す，本支承は，等価剛 性 $1.125 \mathrm{kN} / \mathrm{mm}$ であり, カウンターウエイトと上段フレ 一ムを水平力支持できるように設計されたものである.

カウンターウエイト (440kN 程度) と上段フレームの 総重量は計 500kN程度であった。この重量は，供試体の 設計時に想定した上部構造死荷重の 300kN より大きくし たものであった．本加振装置を用いる実験では，DCSB が終局状態に達した後，上段フレームに対する凸部の拘 束がなくなり, 入力地震動に従って上段フレームに大き な応答変位が生じることがある。ゴム支承を含む実験装 置の安全性を考慮に入れ，DCSB が終局状態に達した後 においても，上段フレームに過大な応答変位を生じさせ ないようにすることが望ましい，そのため，実験では， カウンターウエイトの重量を大きくし，上段フレームの 応答を抑えるようにすることにした，後述の実験結果の 図-19 (d) に示すように，上段フレームの応答変位は最大 87.1mm であった. ゴム支承のせん断ひずみに換算する と 109\%（87.1mm/80mm）となる.

入力地震波形には, 平成 24 年道路橋示方書 - 同解説 $\mathrm{V}$ 而震設計編 ${ }^{12)}$ のレベル 2 タイプ I 地震動（I-II-2，II 種
表-2 ゴム支承 (上段) の仕様

\begin{tabular}{c|c}
\hline 項目 & 值 \\
\hline \hline 橋軸方向有効寸法 & $300 \mathrm{~mm}$ \\
\hline 橋直方向有効寸法 & $300 \mathrm{~mm}$ \\
\hline ゴム 1層厚 $\times$ 層数 & $10 \mathrm{~mm} \times 8$ 層 \\
\hline 内部鋼板厚 $\times$ 枚数 & $3.2 \mathrm{~mm} \times 7$ 枚 \\
\hline せん断弾性係数 & $1.0 \mathrm{~N} / \mathrm{mm}^{2}$ \\
\hline 等価水平剛性 & $1.125 \mathrm{kN} / \mathrm{mm}$ \\
\hline
\end{tabular}

地盤）及びレベル 2 タイプ II 地震動（IIIII-2，II 種地盤） の 2 つの標準波形を使用した．図-13 に，I-II-2 と IIII-2 地震動の加速度波形を示寸．なお，I-II-2 地震動を用い た加振では，加振時間を短縮するため，150 秒以降の波 形をカットした. 150 秒以降の波形は, 加速度振幅が小 さく, 凸部の変形状況や取付ボルトの軸力に着目する本 研究の検討に特に影響がないと考えられる.

加振方法には, 漸増加振と一発破壊加振の 2 種類の加 振方法を用いた。 漸増加振は, 同一DCSB 供試体に対し, 入力地震波形の加速度振幅を小さいレベルから段階的に 大きくして, DCSB が終局状態に達するまで数回に加振 する方法である。一発破壊加振は，漸増加振において DCSB 凸部が終局状態に達した際の加速度振幅の入力レ ベルを用い， 1 回の加振で DCSB 供試体が終局に達する ように加振する方法である. 表-3 に加振ケースの一覧 を示す. 表中の加速度振幅の入力レベルは, 元の加速度 波形の振幅に対する縮小パーセンテージである．加振装 置の振動特性を把握するための 2 方向加振の No.7 と No.11 では, 実験装置の安全上のことを考慮し, 上段フ レームに過大な応答変位が生じないように入力振幅の最 


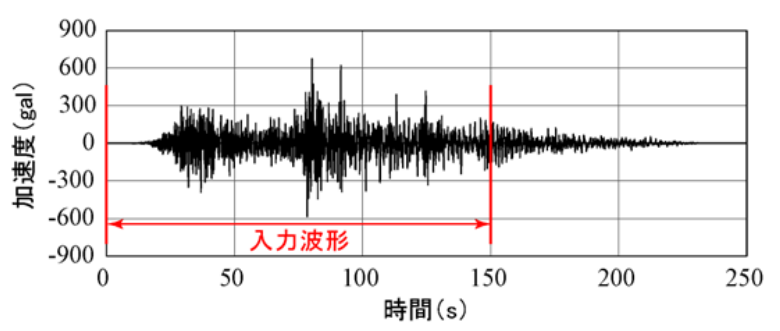

(a) タイプ (I-II-2) 標準波形

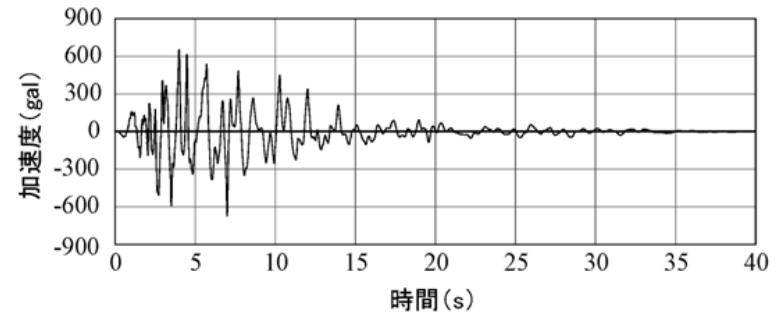

(b) タイプII (II-II-2) 標準波形

図-13 入力地震動の加速度波形

表-3 動的加振ケースの一覧

\begin{tabular}{|c|c|c|c|c|c|c|c|}
\hline No. & 加振ケース & $\begin{array}{c}\text { DCSB設置 } \\
\text { の有無 }\end{array}$ & 入力波形 & 加振方向 & 加振方法 & $\begin{array}{l}\text { 加速度振幅 } \\
\text { の人力レベル }\end{array}$ & 備考 \\
\hline 1 & 動I-1 & 有 & タイプI & 橋直方向 & \multirow{4}{*}{ 一発破壊 } & $100 \%$ & \multirow{4}{*}{$\begin{array}{c}\text { DCSB } の \\
\text { 性能の } \\
\text { 検証 }\end{array}$} \\
\hline 2 & 動I-2 & 有 & タイプI & 橋直方向, 橋軸方向 & & $70 \%$ & \\
\hline 3 & 動II-1 & 有 & タイプII & 橋直方向 & & $70 \%$ & \\
\hline 4 & 動II-2 & 有 & タイプII & 橋直方向, 橋軸方向 & & $60 \%$ & \\
\hline 5 & 動I-1-○\%-無 & $\begin{array}{l}\text { 無 } \\
\end{array}$ & タイプI & 橋直方向 & \multirow{8}{*}{ 漸増加振 } & $30 \%, 50 \%, 70 \%, 100 \%$ & \multirow{8}{*}{$\begin{array}{l}\text { DCSBを } \\
\text { 用いた橋 } \\
\text { 梁の振動 } \\
\text { 特性の検討 }\end{array}$} \\
\hline 6 & 動I-1-○\% & 有 & タイプI & 橋直方向 & & 30\%,50\%,70\%, 100\%（終局） & \\
\hline 7 & 動I-2-○\%-無 & 無 & タイプI & 橋直方向, 橋軸方向 & & $30 \%, 50 \%$ & \\
\hline 8 & 動I-2-○\% & 有 & タイプI & 橋直方向, 橋軸方向 & & 30\%,50\%, 70\%, 80\%（終局） & \\
\hline 9 & 動II-1-○\%-無 & 無 & タイプII & 橋直方向 & & $30 \%, 50 \%, 70 \%$ & \\
\hline 10 & 動II-1-○\% & 有 & タイプII & 橋直方向 & & 30\%, 50\%, 70\%（終局） & \\
\hline 11 & 動I-2-○\%-無 & 無 & タイプII & 橋直方向, 橋軸方向 & & $30 \%, 50 \%$ & \\
\hline 12 & 動II-2-○\% & 有 & タイプII & 橋直方向, 橋軸方向 & & 30\%, 50\%,60\%（終局） & \\
\hline
\end{tabular}

注 : No.5〜No.12のケース名の「○」は，入力パーセンテージである.

大值を $50 \%$ とした.

また，実験では，橋直方向の 1 方向に加振する 1 方向 加振と，橋直方向と橋軸方向の 2 方向に同時に加振する 2 方向加振の 2 種類の加振方法を用いた. 2 方向加振で は，2 方向に同一地震波形を適用した。 ここで，実地震 の場合は，地震力が橋軸に対して任意の方向に作用する 可能性があるが，本研究では，便宜的に橋直方向と橋軸 方向に同様な地震動が作用することと仮定した． 2 方向 に同一地震波形を適用することは，入力波形に位相差が なく, DCSB に作用する外力を定量的に評価しやすいメ リットがある。

計測では，上段フレームの応答加速度，支承部反力， DCSB 凸部ひずみおよび取付ボルト軸力の動波形を記録 した．収録サンプリング周波数は $200 \mathrm{~Hz}$ とした．凸部ひ ずみと取付ボルト軸力の計測箇所は，図-8 に示す通り である.ここで，DCSB 凸部に作用する水平力について は，DCSB 下面のスペースが狭险であることから三分力 計などを設置して直接に計測するのではなく，カウンタ 一ウェイトと上段フレームの慣性力から計算することと した. すなわち，カウンターウェイトと上段フレームの 慣性力は上段フレーム四隅のゴム支承と DCSBによって 受け持つため, カウンターウェイトと上段フレームの慣
性力から 4つの支承反力を減じた值を凸部に作用した水 平力とした.

\section{(2) 動的加振実験結果}

図-14〜図-17 に，表-3 の No.1〜No.4 加振ケースの DCSB 反力，ボルト軸力および凸部ひずみの時刻歴を示 す.いずれの図には，全加振期間の結果とともに，Aの 凸部降伏時と B $の$ DCSB 反力最大時付近の 1.0 秒間の時 刻歴の拡大図も示している. ここで, DCSB は押される 方向にしか抵抗しないため, 図-14〜図-17 の各時刻歴は 片方向（正方向）だけのものとなっている.

図-14 (a) の凸部ひずみの時刻歴より，44.63 秒付近で 凸部のひずみ S1〜S5 は一斉に降伏ひずみに達したこと が見られる.これは，静的載荷実験と同様，設計思想の 通りに凸部高さ方向全断面が同じタイミングで降伏した ことを意味する. 凸部が降伏に達した後，塑性ひずみが 残留するようになり，全加振期間のひずみの時刻歴から 分かるように，加振時間（衝突回数）の増加に伴って凸 部の塑性ひずみが階段的に増加する状況であった。図15〜図-17 の他の加振結果からも同様なことが見られる. DCSB 反力とボルト軸力については，図-14 (b)に示す ように，凸部と上沓の衝突に応じて時刻歴に複数のピー 

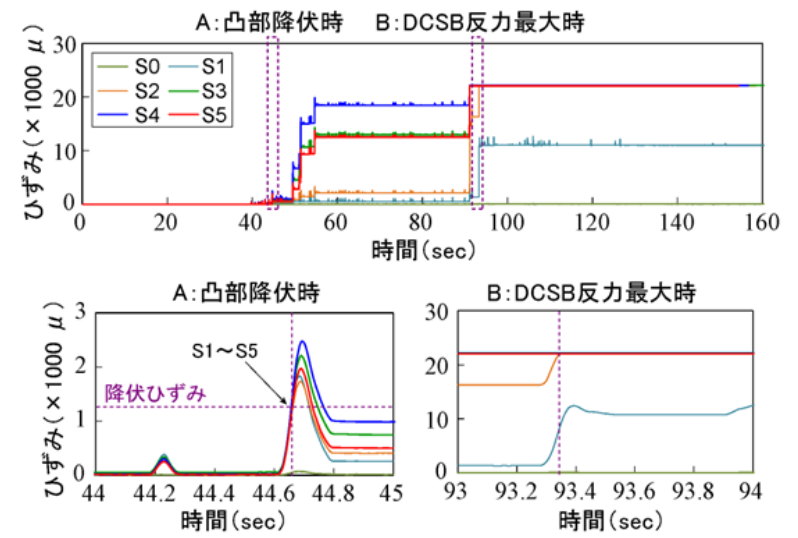

(a) 凸部ひずみ
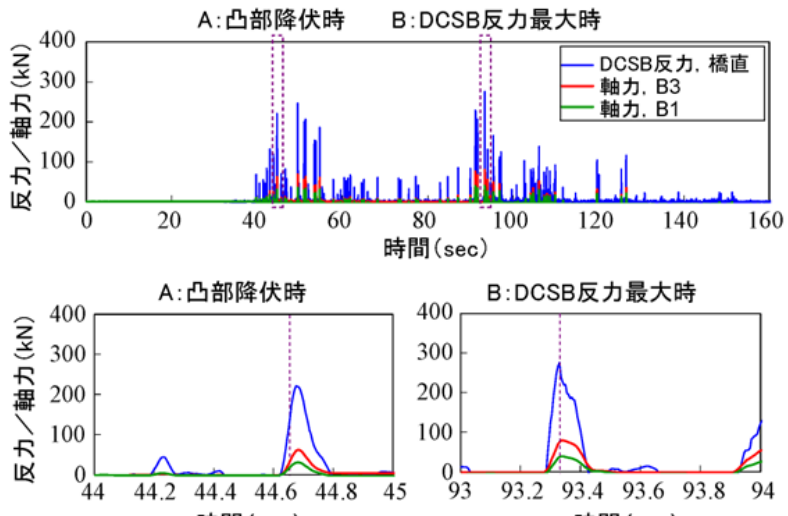

時間 (sec)

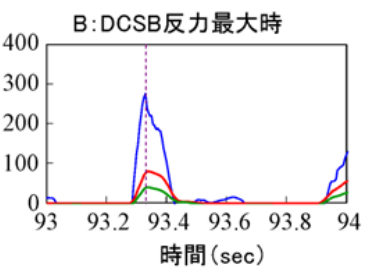

(b) DCSB反力とボルト軸力

図-14 動-1の凸部ひずみ, DCSB反力とボルト軸力の時刻歴
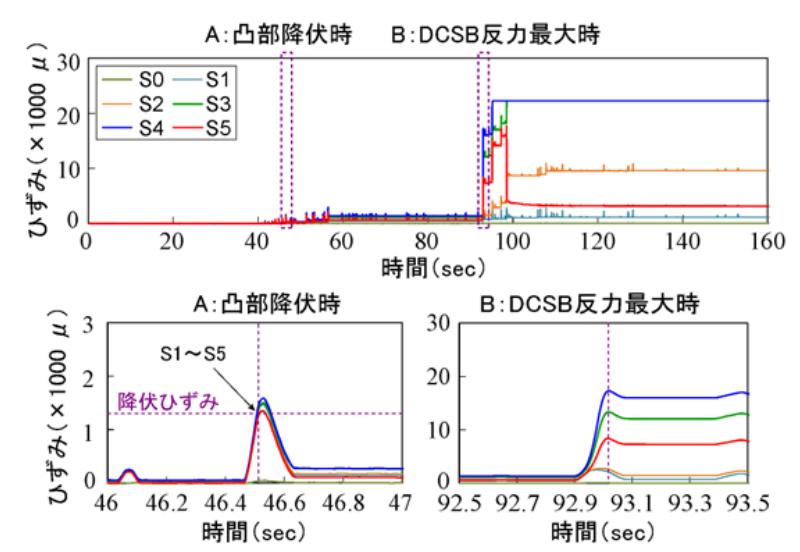

(a) 凸部ひずみ
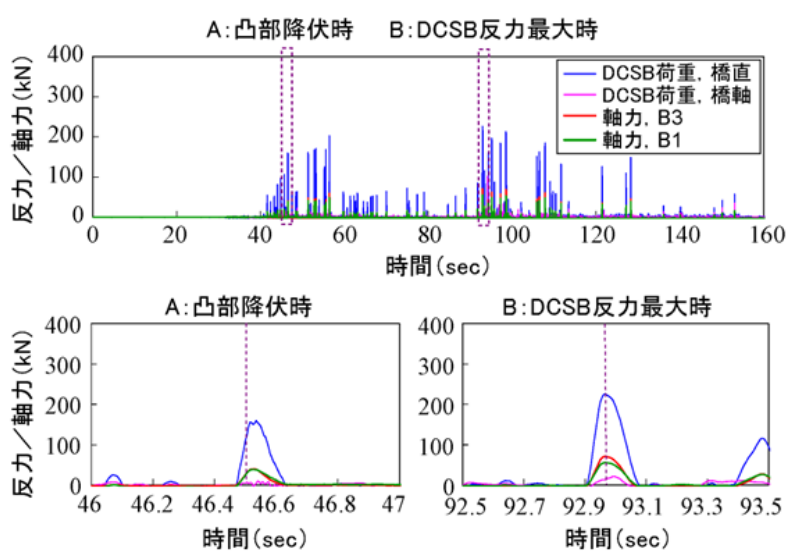

(b) DCSB反力とボルト軸力

図-15 動 I-2 の凸部ひずみ, DCSB 反力とボルト軸力の時刻歴

クが見られる. B の DCSB 反力最大時以降においても多 数のピークが生じていた。 これは，図-10 に示す静的載 荷実験結果の水平荷重-水平変位関係の耐力低下区間の ように，DCSB 反力が最大值になった時点でも，凸部の 水平変形量が移動拘束解放までの変形量に達しておらず, 上段フレームに対する拘束が機能していたことを意味す る. 図-15〜図-17 の他の加振結果からも同様なことが見 られる.

一方，実験終了後の供試体の損傷状況の観察より，い ずれの加振ケースにおいても，凸部のき裂や取付ボルト の損傷が確認されなかった。図-18 に，一例として実験 終了後の凸部の変形状況および取付ボルトの状況写真を 示す. (a) 図より, 実験終了後の凸部は塑性変形が高さ 方向に分散し，凸部全体が緩やかに曲がっていることが 分かる. 取付ボルトについては，(c) 図に示すようにネ ジ山などに明瞭な損傷はなく，実験後に電動工具を使用 して簡単に取り外すことができた。

以上の結果より，動的作用下の DCSBは，設計で考慮 していた移動拘束効果を発揮したとともに，終局状態に おいても凸部や取付ボルトに明瞭な損傷が生じていなか
つたことを確認した. 加振方法による実験結果の差異に ついて， 1 方向加振と 2 方向加振に用いた地震動の入 カレベルに差があったために実験結果の絶対值の比較が できないが，凸部の反力やひずみの発生形態や凸部の損 傷状況に明確な違いは見られなかった。 なお，加振方法 による取付ボルト軸力への影響については 6 章に説明す る.

\section{6. 取付ボルトの軸力}

フランジ中央のボルト B3 と端部のボルト B1 の軸力 を考察し, ボルトの設置位置や地震力の作用方向による 軸力への影響を検討する.

表-4 に，静的載荷実験と動的加振実験の取付ボルト の軸力の一覧を示す. いずれの実験ケースにおいても, フランジ中央のボルト B3 は端部のボルト B1 より軸力 が大きかった。両者の割合（B3／B1）は，載荷方法に よって異なっており, 橋直方向の 1 方向載荷の場合は 1.9〜2.4で，2方向載荷の場合は 1.2～1.3であった. 2 方 

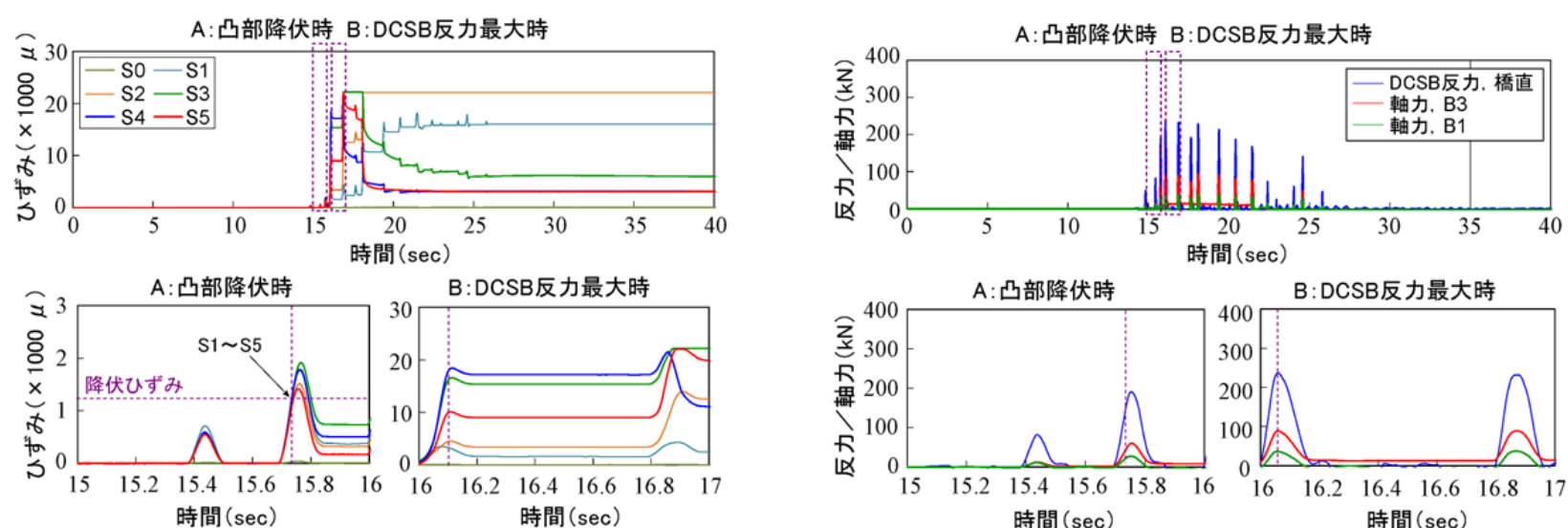

(a) 凸部ひずみ

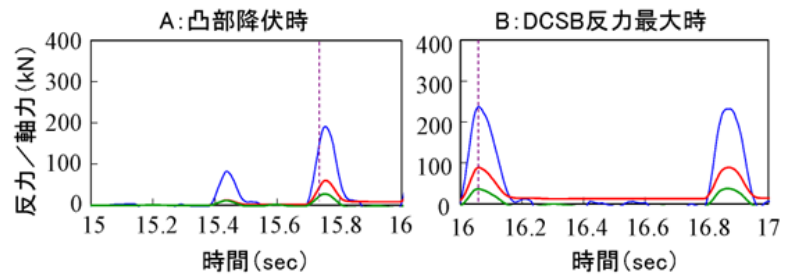

(b) DCSB反力とボルト軸力

図-16 動I-1の凸部ひずみ，DCSB反力とボルト軸力の時刻歴
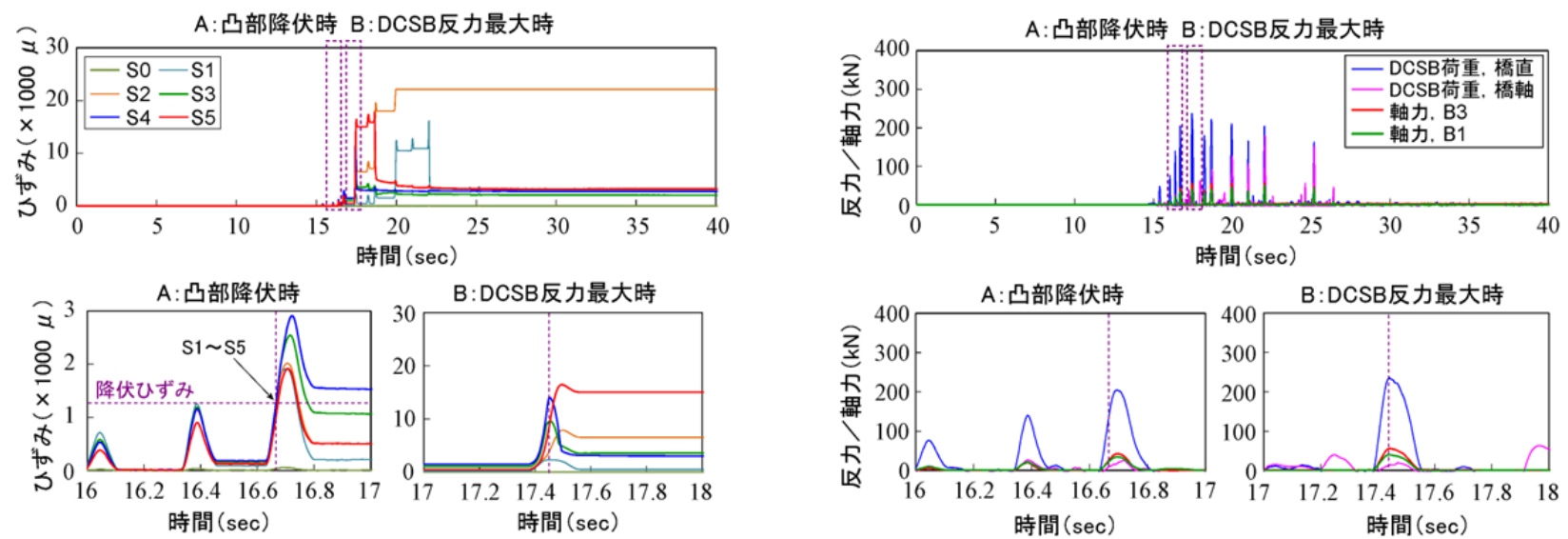

(a) 凸部ひずみ
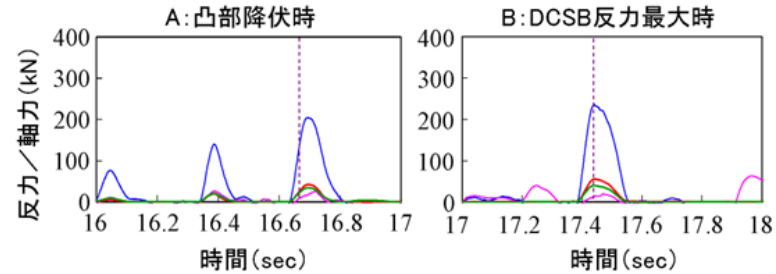

(b) DCSB反力とボルト軸力

図-17 動 II-2の凸部ひずみ，DCSB 反力とボルト軸力の時刻歴

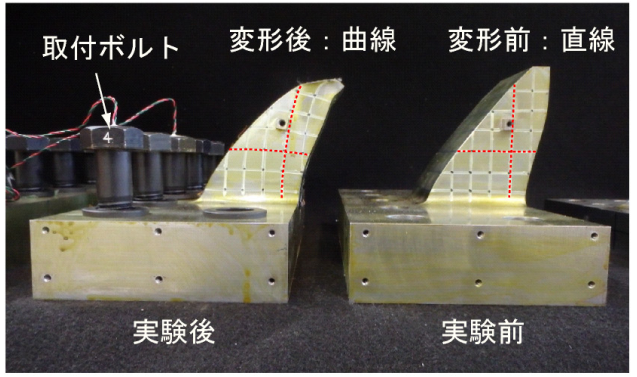

(a) 凸部の橋直方向の変形状況

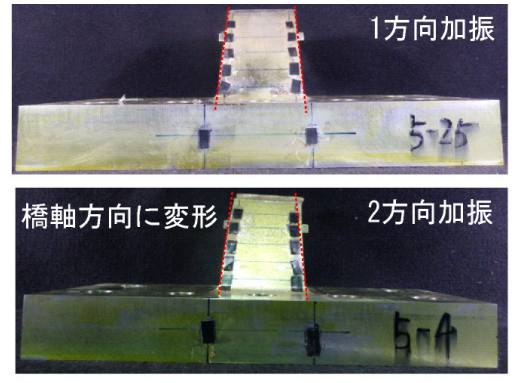

(b) 凸部の橋軸方向の変形状況

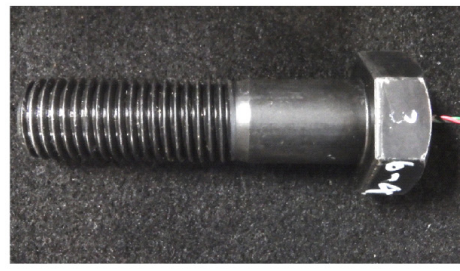

(c) 取付ボルトの状況

図-18 実験後の供試体状況

表-4 各実験ケースの取付ボルトの軸力

\begin{tabular}{|c|c|c|c|c|c|}
\hline \multirow{2}{*}{$\begin{array}{l}\text { 実験 } \\
\text { 方法 }\end{array}$} & \multirow{2}{*}{$\begin{array}{l}\text { 実験 } \\
\text { ケース }\end{array}$} & \multicolumn{2}{|c|}{ ボルト軸力の最大值 $(\mathrm{kN})$} & \multirow{2}{*}{$\mathrm{B} 3 / \mathrm{B} 1$} & \multirow{2}{*}{$\begin{array}{c}\text { B3の軸力の安全率 } \\
\text { (保証耐力/軸力) }\end{array}$} \\
\hline & & B1 & B3 & & \\
\hline \multirow{2}{*}{$\begin{array}{c}\text { 静的載荷 } \\
\text { 実験 }\end{array}$} & 単調載荷 & 40.1 & 78.9 & 2.0 & 2.7 \\
\hline & 片方向変位漸増繰返し載荷 & 39.8 & 75.2 & 1.9 & 2.9 \\
\hline \multirow{4}{*}{$\begin{array}{c}\text { 動的加振 } \\
\text { 実験 }\end{array}$} & 動I-1 & 42.3 & 84.4 & 2.0 & 2.5 \\
\hline & 動I-2 & 57.6 & 73.3 & 1.3 & 2.9 \\
\hline & 動II-1 & 40.6 & 95.7 & 2.4 & 2.2 \\
\hline & 動П-2 & 53.3 & 63.1 & 1.2 & 3.4 \\
\hline
\end{tabular}




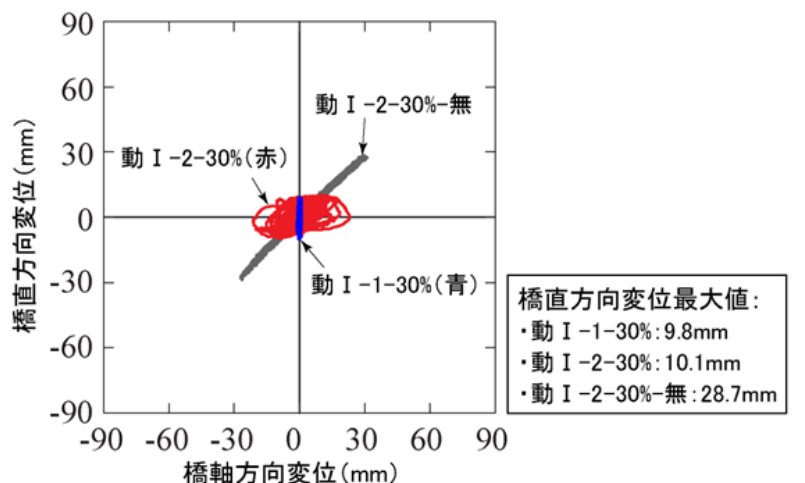

(a) $30 \%$ 入力

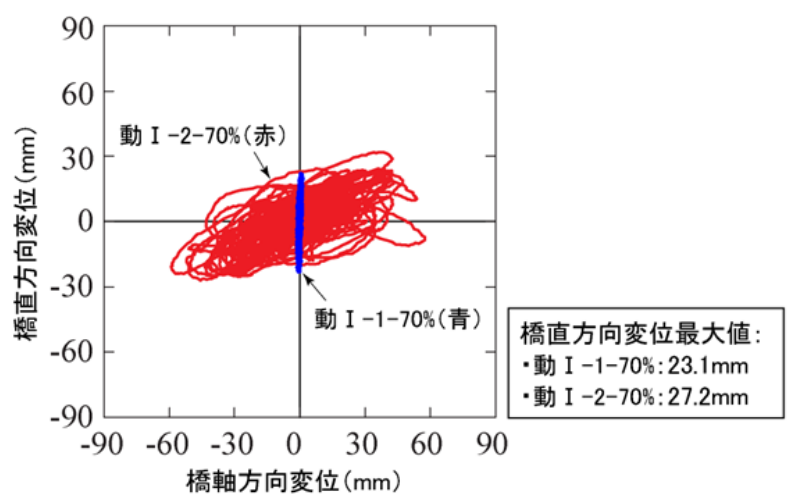

(c) $70 \%$ 入力

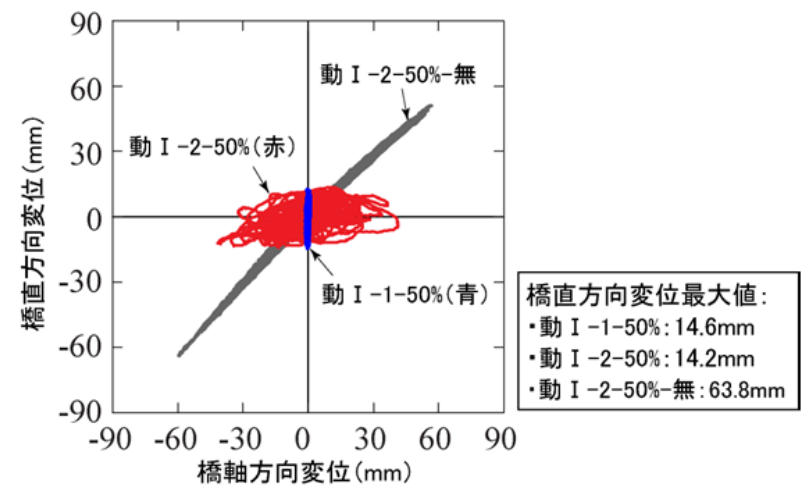

(b) $50 \%$ 入力

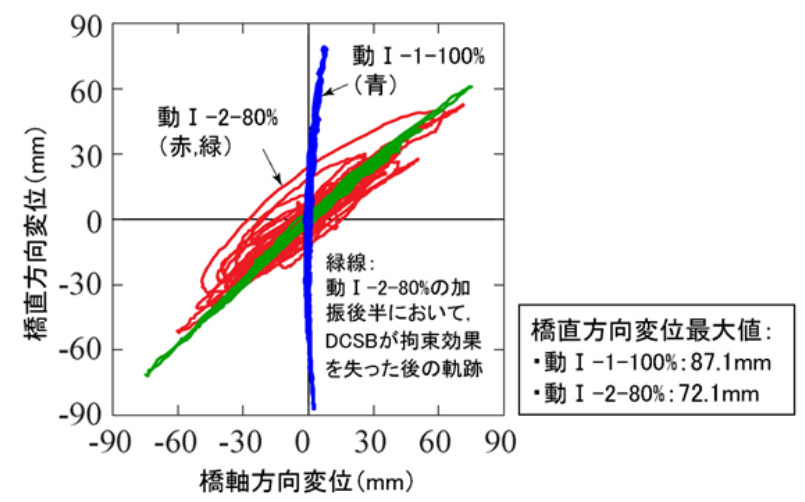

(d) 1方向加振 : $100 \%$ 入力, 2 方向加振 : $80 \%$ 入力

図-19 上段載荷フレームの応答変位の軌跡

向載荷の場合では，前述のように，橋軸方向の地震力成 分によって凸部に橋直方向軸まわりのモーメントが生じ, それによってフランジ端部ボルト B1 の軸力が 1 方向加 振より大きく生じた. 一方, 軸力が大きかった B3 ボル トの安全率である「保証耐力（212kN）/ボルト軸力」に ついては，1方向載荷の場合は 2.2 2.9で，2方向載荷の 場合は 2.9〜3.4であった.

これらの結果より, 取付ボルトの軸力は均一ではなく, フランジ中央のボルトは端部のボルトより軸力が大きか ったこと，また，加振方法によって中央と端部のボルト の軸力のバランスも異なったことが分かる．凸部の終局 耐力に対する取付ボルトの軸力の安全率は，本実験の条 件下では 2.2〜3.4 であった。この安全率は，ボル卜軸方 向の直応力だけを考慮したもので，計算方法による安全 余裕度や設計時に考慮した安全マージンなどが含まれた ものとなる. せん断応力を考慮すると安全率が低くなる. 今後, DCSB の実用化に向けて, 取付ボルトの適切な設 計・照査方法の更なる検討を行っていく予定である.

\section{DCSB を用いた橋の動的挙動}

\section{(1) 上部構造の応答変位}

凸部の塑性変形の進行に伴う上部構造の動的挙動の変
化を明らかにするため，表-3 に示す No.5〜No.12 の各漸 増加振ケースにおける上段フレームの応答変位および态 答加速度から求めた卓越振動数の変化を考察することと した. 入力地震動の種類に関わらず同様な傾向が見られ たが，以下に，タイプ I 地震動を用いた加振結果に基づ た考察を示寸.

図-19に，DCSB を設置していない場合（以下，DCSB 無）の 2 方向加振，DCSB を設置していた場合の 1 方向 加振および 2 方向加振の加振レベル毎の上段載荷フレー ムの応答変位の軌跡を示す.ここで, 加振レベルと DCSB の変形状態との対応関係については, 図-19 の橋 直方向変位を図-10 の水平変位-水平荷重関係と照らし 合わせてみると，30\% および 70\% 入力時の DCSB 凸部 の変位量は，それぞれ，静的実験結果の降伏時および最 大荷重時の変位量と概ね一致していることが分かる.

図-19(a) と (b) より，加振装置の振動特性を検討寸る ための DCSB 無の動 I-2-30\%-無と動 I-2-50\%-無では, DCSB による移動拘束がないため, 地震波形の入力方法 に従った結果として橋軸方向と橋直方向の 2 方向の応答 変位が同様であることが見られる.これらの結果と比べ, 図-19(a) 〜 (c) に示す DCSB を有した動 I-2-○\%では，凸 部の移動拘束によって, 橋直方向応答変位（縦軸）が橋 軸方向応答変位（横軸）より小さく生じた，例えば，図 -19(b) に示寸動 I-2-50\%の場合は, 橋軸方向応答変位の 


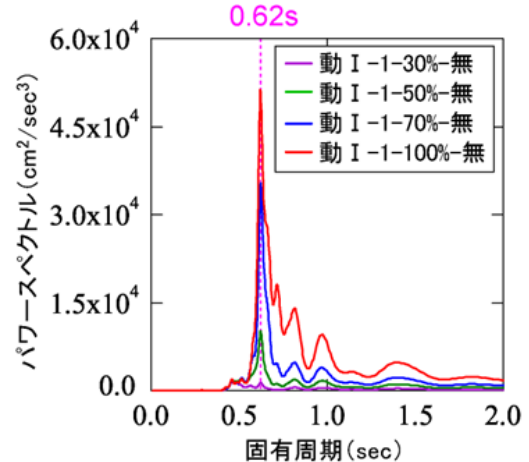

(a) DCSB無

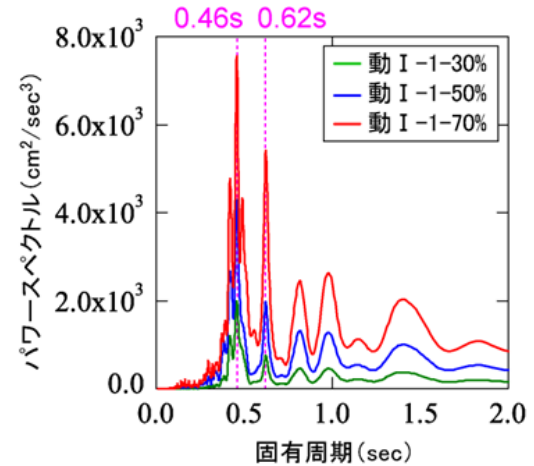

(b) DCSB有，30\%，50\%，70\%入力

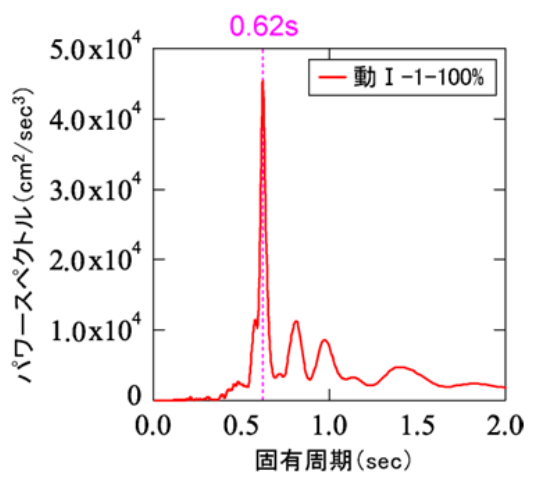

(c) DCSB有, $100 \%$ 入力

図-20 上段フレームの応答加速度のパワースペクトル（1方向加振，橋直方向成分）

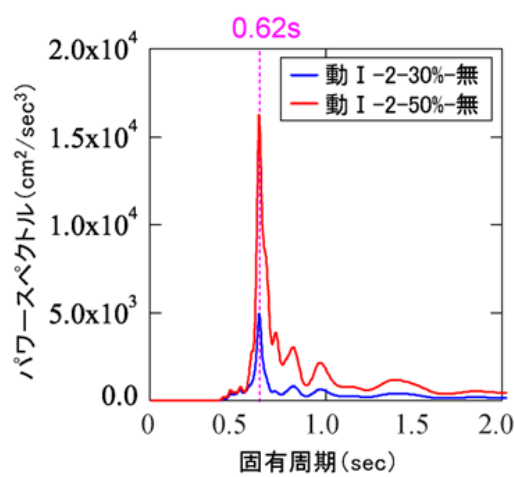

(a) DCSB無

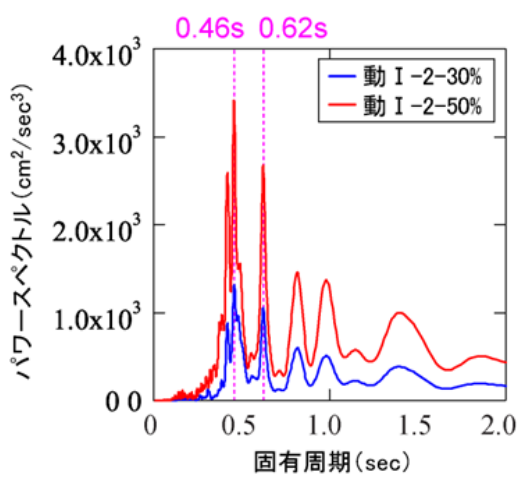

(b) DCSB有, $30 \%, 50 \%$ 入力

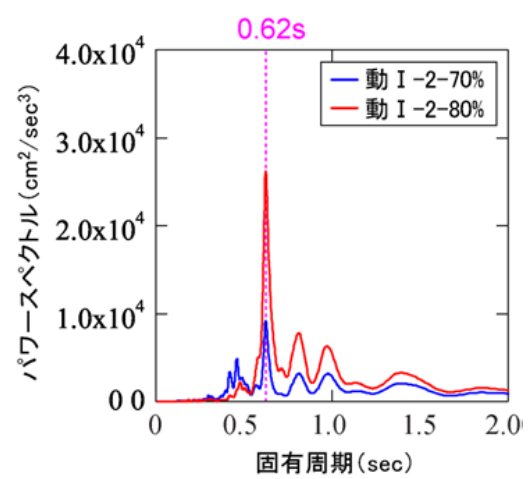

(c) DCSB有, $70 \%$ ， $80 \%$ 入力

図-21 上段フレームの応答加速度のパワースペクトル（2方向加振，橋直方向成分）

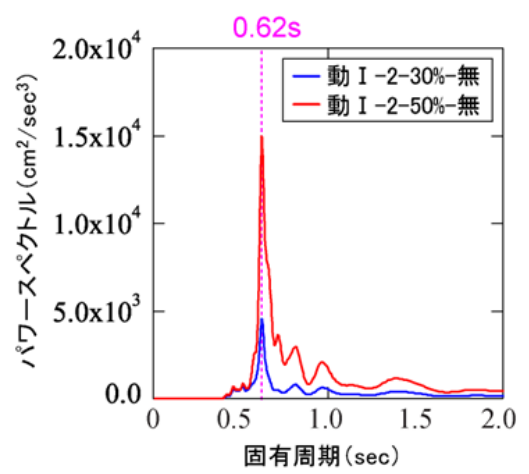

(a) DCSB無

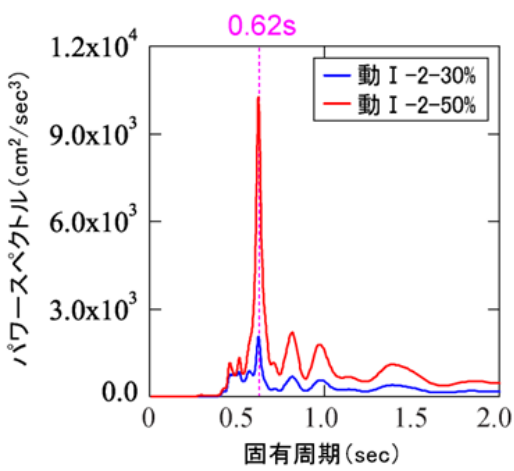

(b) DCSB有, 30\%，50\%入力

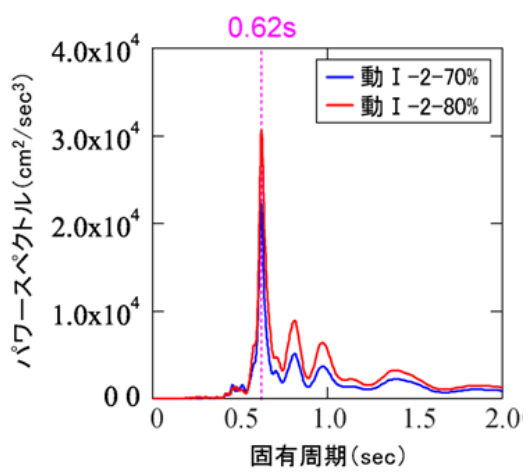

(c) DCSB有， $70 \% ， 80 \%$ 入力

図-22 上段フレームの応答加速度のパワースペクトル（2方向加振，橋軸方向成分）

$41.5 \mathrm{~mm}$ に対し，橋直方向応答変位がその約 $1 / 3$ の 14.2mm であった. また，図-19(a)〜 (c) より，同じ加振 レベルの 1 方向加振と 2 方向加振の橋直方向変位は，概 ね同様であることが分かる。

図-19(d) に凸部が終局状態（図-4(b) に示す状態）に達 した加振レベルの加振結果を示す. 動 I-2-80\% の応答変 位の軌跡の変化を分かりやすくするために，DCSB が移 動拘束効果を失った加振後半の軌跡を緑線とした. 緑線 は，加振前半の赤線と比べ，2 万向の応答変位の差異が 小さくなり, DCSB 無と類似な応答変位軌跡であった. これは，凸部が終局状態に達し，上段フレームの移動拘 束が解放されたことによって 2 方向に同様な応答変位が
生じるようになったためである.

一方，図-19 (a)と(b) より，DCSBを有した加振ケース 動 I-2-30\%と動 I-2-50\%では，橋直方向とともに，橋軸方 向の応答変位も DCSB無の場合より小さかったことが分 かる. これは，2 方向加振では，載荷プレートが斜め方 向に凸部に衝突したため, 橋軸方向における凸部の抵抗 によって橋軸方向の応答変位も抑制されたことによるも のである.

\section{（2）上部構造の振動特性}

図-20～図-22 に，1 方向加振の橋直方向，2 方向加振 の橋直方向および橋軸方向の上段フレームの応答加速度 
のパワースペクトルを示す.いずれの図において，(a) 図は DCSB 無の各加振レベルの結果，(b) 図は凸部が終 局状態に達する前の各加振レベルの結果，(c) 図は終局 に達した加振レベルの結果である.

DCSB 無の場合については，図-20(a)〜図-22(a) より, 加振方法や加振レベルによらず，いずれの加振ケースも 卓越周期が 0.62sであったことが分かる.

DCSB 有の橋直方向成分については，図-20(b) と (c) の 1 方向加振の場合は，30\%，50\%および 70\%入力では 0.46s 付近で最も卓越していたが，100\%入力では DCSB 無の場合と同様に 0.62s 付近が卓越するようになった.

図-21(b) と (c) の2方向加振の場合は，1方向加振と同様 な傾向として，低い加振レベルの 30\%と 50\%入力では 0.46s 付近，高い加振レベルの $70 \%$ と $80 \%$ 入力では $0.62 \mathrm{~s}$ 付近が最も卓越していた．これは，低いレベルの入力で は，凸部の塑性変形が未だ顕在化していないため，上段 フレームの応答変位が抑制され，上段フレームが短い周 期で振動していたが，入力レベルを大きくしたことに伴 って凸部の塑性変形が大きくなり，上段フレームが DCSB 無の場合と概ね同様に振動するようになったこと によるものである.

DCSB 有の橋軸方向成分については，図-22(b) と (c)に 示すように，加振レベルに関わらず DCSB無の場合と同 様に0.62s 付近で卓越していたことが分かる.

以上の結果より, DCSB を用いる橋梁の上部構造は, 凸部の塑性変形が顕在化する前は DCSBによって拘束さ れている状態にあるが，凸部の塑性変形の増大に伴って 段々にDCSB を用いていない場合と同様な振動特性にな ることが明らかになった。

\section{8. まとめ}

本研究では，地震時における支承サイドブロック部材 の高架下への落下による第三者被害のリスクを低減させ るための対策として, 従来型サイドブロックと同様な機 能を有しかつ取付ボルトの破断などの脆性破壊を生じさ せない新たな損傷制御型サイドブロックである DCSBを 提案した. 実物大 DCSB 供試体に対して実施した静的載 荷実験および動的加振実験に基づき, DCSB の性能とと もに, DCSB を用いた橋梁の動的挙動を詳細に検討した. 本研究より得られた結果は, 以下のようである.

1) 提案した凸部形状および取付ボルトの配置方法を用 いた DCSB は, 設計思想の通りに上部構造に対する 移動拘束および移動拘束の開放が発揮でき，また， 終局状態においても凸部のき裂や取付ボルトの破断 などの脆性破壞が生じなかったことを確認した.

2) 凸部の塑性ひずみを高さ方向に分散させるために,
高さ方向の各断面の合成応力度を同じにして凸部の 断面形状を設計した. 実験結果より, 高さ方向の各 断面が同じタイミングで降伏し, 凸部全体が緩やか に変形したことが確認できた.

3）地震力に対する取付ボルトの抵抗をより合理的にす るために，凸部前面にボルトを配置するように新た な取付ボルトの配置方法を提案した. 本研究で実施 した各実験ケースでは, 凸部の終局耐力に対する取 付ボルトの軸力の安全率（保証耐力／ボルト軸力） は2.2〜3.4であった.

4) DCSB の取付ボルトの軸力は，ボルトの設置位置や 加振方向によって異なっていた. フランジ中央のボ ルトは，端部のボルトより軸力が大きく生じた．本 実験の条件下での両者の比率は, 橋直方向の 1 方向 加振の場合は 1.9 2.4 程度, 2 方向加振の場合は 1.2 〜1.3程度であった.

5）DCSB を用いた橋梁は, 凸部の塑性変形の進行に従 って上部構造の振動特性も変化することが確認され た. DCSB の移動拘束効果が発揮している間は，上 部構造の橋直方向の応答変位が抑制されるが, DCSB の役割を果たして移動拘束を開放した後は, 上部構造の振動特性は DCSB を設置していない場合 と同様になる.

謝辞 : 本研究は, 国立研究開発法人土木研究所, 株式会 社高速道路総合研究所, 阪神高速道路株式会社, 名古屋 高速道路公社および首都高速道路株式会社による「支承 の長期耐久性に関寸る共同研究（平成 26 年度〜平成 27 年度）」において首都高速道路グループが主体となって 実施したものである. 開発にあたっては共同研究のメン バーから多くの助言や協力をいただいた．この場を借り て御礼申し上げる.

\section{参考文献}

1) 平成 23 年（2011 年）東北地方太平洋沖地震による 道路橋等の被害調查報告, 国総研資料, 第 814 号, 土研資料，第 4295 号，2014.12.

2) 山川糧平, 鵜野禎史, 原田孝志, 増田耕一, 朝倉康 信, 大堀宏之: 東北地方太平洋沖地震後の支承調查 報告, 土木学会第 67 回年次学術講演会, pp. 11-12, 2016.9.

3) (一社) 日本橋梁建設協会: 熊本地震橋梁被害調查報 告書, 2016.10 .

4) 渡邊学歩, 葛西昭, 松永昭吾, 益田諒大：2016 年熊 本地震による大切畑大橋の被害分析, 第 19 回性能 に基づく橋梁等の耐震設計に関するシンポジウム講 演論文集, 土木学会, pp. 177-184, 2016.7.

5）（公社）日本道路協会：道路橋支承便覧（改訂版）, 2004.4.

6) 坂井田実, 吉田雅彦, 北田俊行, 松村政秀 : 支承业 イドブロックにおける破断特性制御構造の提案, 土 
木学会地震工学論文集, Vol. 27, 2003.12.

7) 中西泰之, 松村政秀, 山口隆司：ノックオフ型サイ ドブロックを併設した免震高架橋の地震時挙動, 鋼 構造論文集, Vol. 22, No. 86, pp. 23-32, 2015.

8) 本田利器, 秋山充良, 片岡正次郎, 高橋良和, 野津 厚，室野剛隆：「危機耐性」を考慮した耐震設計体 系一試案構築にむけての考察一, 土木学会論文集 A1 (構造 - 地震工学) , Vol. 72, No. 4, pp. I_459I_472, 2016.

9) 中央防災会議 首都直下地震対策検討ワーキンググル ープ: 首都直下地震の被害想定と対策について（最 終報告），2013.12.
10）蔵治賢太郎, 右高裕二, 張広鋒, 大住圭太 : 地震時 の損傷を制御する支承サイドブロックの FEM 解析 による形状検討, 土木学会第 70 回年次学術講演会, pp. 271-272, 2015.9.

11) 張広鋒, 和田新, 右高裕二 : FEM 解析による損傷制 御型サイドブロック取付ボルトの配置方法の検討, 土木学会第 71 回年次学術講演会, pp. 473-474, 2016.9.

12) 道路橋示方書 - 同解説 $\mathrm{V}$ 而震設計編, 2012.3.

\section{STUDY ON A NEW TYPE OF SIDE BLOCK FOR CONTROLLING SEISMIC DAMAGE OF BRIDGE BEARING}

\section{Guangfeng ZHANG, Kentaro KURAJI, Arata WADA, Yuuji MIGITAKA and Keita OSUMI}

It was confirmed from the recent earthquakes that fracture of set bolts for side block was a typical damage pattern for bridge bearings. Fractured set bolts or the body of the side block which was loosened due to the fracture of set bolts may fall down below the viaduct and may cause third-party damage to passing vehicles or to pedestrians. In this study, a new type of side block named as damage-controlled side block (DCSB) was proposed for highway bridges with the purpose of preventing third-party damage in a severe earthquake due to the falling of the damaged side block parts. A DCSB was designed with high ductility without brittle damage such as fracture of the stopper or the set bolts. Load-carrying capacity and plastic behavior of the DCSB were examined by static tests and shake table dynamic tests on fullscale specimens. As a result, it was concluded that the performance of the DCSB satisfied the requirements considered in the development. Furthermore, dynamic behavior of the superstructure with the varying of the plastic condition of the DCSB was investigated basing on the results of the shake table dynamic tests. 